\title{
29. PETROLOGIC STUDIES OF BASEMENT LAVAS FROM NORTHWEST PACIFIC GUYOTS ${ }^{1}$
}

\author{
David M. Christie, ${ }^{2}$ Julie J. Dieu, ${ }^{3}$ and Jeff S. Gee ${ }^{3}$
}

\begin{abstract}
Leg 144 of the Ocean Drilling Program (ODP) recovered lavas and volcaniclastics from the volcanic basement of five northwest Pacific guyots (Limalok, Lo-En, and Wodejebato guyots in the Marshall Islands group; MIT Guyot, an isolated edifice midway between the Marshall Islands and Japan; and Takuyo-Daisan Guyot in the Japanese seamount group). Most of the lavas have undergone extensive low-temperature alteration, but their petrography, mineral chemistry, and, in some cases, whole-rock chemistry clearly demonstrate that almost all are of alkalic affinity, ranging from highly magnesian basanites to hawaiites. The sole exception is the single lava recovered from Takuyo-Daisan, which is tholeiitic or transitional in character.

Tectonic reconstructions suggest that all the seamounts investigated during Leg 144 originated, in Cretaceous time, as intraplate volcanoes in what is now known as the SOPITA (South Pacific isotopic and thermal anomaly) region. One of the principal objectives of basement sampling was to determine whether the present-day manifestations of this region have persisted since the Cretaceous or whether they have evolved through time. Ratios and relative abundance patterns of those incompatible trace elements that are not readily affected by alteration processes are remarkably uniform in the Leg 144 alkalic lavas, falling well within the overall field of modern SOPITA lavas and strongly resembling those of Tahiti in particular. In this uniformity, they differ from the pronounced diversity of modern SOPITA lavas, although the sample is rather small. Thus, the Cretaceous SOPITA mantle source was little different in trace element abundances from today, although the Leg 144 data do not preclude an increase in diversity through time.
\end{abstract}

\section{INTRODUCTION}

Many of the myriad submarine volcanoes that make up the northwest Pacific Cretaceous seamount province (see site map preceding the title page) originally formed in a region of the South Pacific that is characterized today by the presence of numerous volcanic island chains and has been called the "Pacific Superswell" (McNutt and Fischer, 1987) and, more recently, the South Pacific isotopic and thermal anomaly (SOPITA) (Smith et al., 1989; Staudigel et al., 1991). In addition to its numerous intraplate volcanoes, this region is characterized by an unusually weak lithosphere and unusually warm underlying mantle. In geochemical terms, SOPITA lavas are characterized by the great diversity of their trace element and isotopic compositions as well as by the locally extreme, long- and short-term enrichment in incompatible trace elements that characterizes their mantle source regions. These characteristics vary considerably, and apparently unsystematically, over short distances and on short time scales throughout the SOPITA region.

The limited data on the ages and compositions of volcanic rocks and volcanogenic sediments from northwest Pacific seamounts that were available before Ocean Drilling Program (ODP) Legs 143 and 144 (see Lincoln et al., 1993, and Winterer et al., 1993, for recent reviews) are also best categorized in terms of their diversity. These volcanoes also appear to vary in age and in their geochemical character in an apparently unsystematic way. One of the major objectives of Legs 143 and 144 was to examine the nature of the SOPITA mantle source during the Cretaceous, through an investigation of the petrology and geochemistry of lavas from a number of Northwest Pacific volcanoes.

In this paper, we summarize our shipboard petrographic observations and our interpretations of the geological history of each of the guyots, insofar as it is recorded in the core. We also present the results of our shipboard and subsequent geochemical studies, which show

${ }^{1}$ Haggerty, J.A., Premoli Silva, I., Rack, F., and McNutt, M.K. (Eds.), 1995. Proc. $O D P_{2}$ Sci. Results, 144: College Station, TX (Ocean Drilling Program).

College of Oceanic and Atmospheric Sciences, Oregon State University, Corvallis, OR 97331-5503, U.S.A.

${ }^{3}$ Scripps Institution of Oceanography, University of California at San Diego, La Jolla, CA 92093-0218, U.S.A. that there has been no discernible change in the petrology of lavas from the SOPITA region or in the geochemistry of their source region(s) during the last $100 \mathrm{Ma}$. Isotopic data (Koppers et al., this volume), mineral chemistry (Dieu, this volume), and radiometric as well as paleomagnetic dating (Pringle et al. and Gee et al., both in this volume) all support the hypothesis that the SOPITA region had many of the same characteristics in the Cretaceous as it does today.

\section{ANALYTICAL TECHNIQUES}

With one exception, X-ray fluorescence (XRF) spectrometry analyses were carried out aboard JOIDES Resolution. Methods are reported in the "Explanatory Notes" chapter of the Leg 144 Initial Reports volume (Premoli Silva, Haggerty, Rack, et al., 1993). A single sample (144-874B-24R-4, 26-32 cm; Tables 1 and 2) was analyzed by XRF at the University of Massachusetts at Amherst. This sample was powdered at the Scripps Institution of Oceanography (SIO) by sawing and polishing thin slabs and crushing them in a ceramic jaw crusher. The crushed sample was leached in $10 \% \mathrm{HCl}$, rinsed twice in distilled water (10 min. each step, ultrasonic bath), dried in a warm oven, and powdered in an alumina ball mill.

Samples were dissolved for inductively coupled plasma mass spectrometric (ICP-MS) analysis at both SIO and Oregon State University (OSU) and analyzed using a VG-Fisons PQ2+ instrument at OSU. At SIO, samples were dissolved in a 2:1 mix of ultrapure HF and distilled $\mathrm{HNO}_{3}$ followed by two $\mathrm{HNO}_{3}$ rinses and then were diluted 1000 -fold in a $3 \% \mathrm{HNO}_{3}$ solution. Blanks were made with the same technique and were subtracted from the analyses. Blank levels were less than $0.5 \mathrm{ppb}$. For the SIO dissolutions, a quantitative calibration was accomplished using pure-element, ICP-MS-grade standard solutions at 5, 10,50, and $100 \mathrm{ppb}$ concentrations for four-point working curves. In (100 ppb) was added to all standards and samples as an internal standard. A well analyzed Samoan olivine nephelinite (UPO-7A) was prepared by the same dissolution method and repeatedly analyzed during the ICP-MS runs. These data were normalized against instrumental neutron activation analysis (INAA) data (by F.A. Frey on the same powder). The xenolith analyses were normalized with these coefficients to eliminate minor rock matrix effects. The repeated analyses of UPO-7A verified instrument stability and repro- 
ducibility. At OSU, 80-mg samples were dissolved overnight in 200 $\mu \mathrm{L}$ of $40 \% \mathrm{HF}$ and $600 \mu \mathrm{L} 8 \mathrm{~N} \mathrm{HNO}_{3}$, dried and redissolved once in $\mathrm{HCl}$ and twice in $\mathrm{HNO}_{3}$, then diluted in $2 \mathrm{~N} \mathrm{HNO}_{3}$ to make a $10-\mathrm{mL}$ stock solution. Before being analyzed, a $1-\mathrm{mL}$ aliquot of this stock solution was diluted to $6 \mathrm{~mL}$ in $1 \% \mathrm{HNO}_{3}$ with sufficient $\mathrm{Be}$, In, and $\mathrm{Bi}$ added to make a 10-ppb internal standard. Four standard rock powders and a reagent blank were prepared along with the samples. Unknown element concentrations were determined relative to calibration curves based on the standard rock and blank solutions. OSU data can be distinguished from SIO data by the greater number of elements determined for the former.

Analyses of minerals for major elements, $\mathrm{Ni}$, and $\mathrm{Cr}$ were obtained using a Cameca CAMEBAX Microbeam electron probe at SIO. Data reduction includes routine ZAF correction. However, analyses were further normalized to analyses of standard minerals (USNM Kakanui Augite; USNM San Carlos Olivine; USNM Lake County Plagioclase) obtained as unknowns.

\section{LITHOLOGY AND PETROLOGY}

In this section, we present brief descriptive summaries of the volcanogenic sections for each of the guyots. Lava types are, for the most part, those identified at sea on the basis of petrography and subsequently confirmed by the whole rock and mineral chemistry. Detailed sample descriptions can be found in Premoli Silva, Haggerty, Rack, et al. (1993).

\section{Limalok Guyot (Site 871)}

\section{General Setting}

Site 871 is located on the flattened upper surface of Limalok Guyot, to the south of its center, in an area where seismic-reflection profiles show a complex, gently south-dipping group of basement reflectors, beneath which more steeply south-dipping structures can be observed. The basement reflector(s) appears to correlate with the deeply weathered upper surface of the basaltic sequence (Premoli Silva, Haggerty, Rack, et al., 1993). Basaltic basement in this region must, therefore, have been exposed by erosion. The minimum basement removed can be calculated by extrapolating a slope from the edge approximately $5 \mathrm{~km}$ away, giving, for example, $250 \mathrm{~m}$ of "missing" section for a $3^{\circ}$ slope. Visible effects of low-temperature hydrothermal alteration are pervasive throughout the lava sequence, possibly suggesting that magmatic activity continued at the site for some time after the eruption of the sampled flows. For these reasons, we suggest that the igneous section most likely represents part of the main constructional phase of the volcano, rather than a short-lived, low-volume, post-erosional phase.

Hole $871 \mathrm{C}$ penetrated approximately $50 \mathrm{~m}$ into volcanogenic basement, formally designated as lithologic Unit IV (Premoli Silva, Haggerty, Rack, et al., 1993). The earliest events recorded in the core from this site are a series of eruptions of highly alkalic basalts, basanites, and nephelinites, forming at least 11 massive flows ranging from 1 to more than $7 \mathrm{~m}$ in thickness. The margins of the flow units are not preserved in the core, so it is not known whether they are submarine or subaerial. Overlying the lavas, $6 \mathrm{~m}$ of angular volcanic breccias and a thick $(30 \mathrm{~m})$, mottled claystone weathering profile record a (long?) period of weathering and erosion of the volcanic pile, which was most likely subaerial initially, but terminated under unequivocally marine conditions.

\section{Lithologic Descriptions}

Material of clear volcanic origin was first drilled at 436 meters below seafloor (mbsf) (Core 144-871C-33R) in the form of isolated pieces of basalt within the sedimentary section, a few meters above igneous basement. Except for a single, thin (approximately $1 \mathrm{~m}$ ) basaltic unit, the uppermost $6 \mathrm{~m}$ of recovered basement consists of a series of volcanogenic breccias. Beneath, the breccias are a sequence of 23 units, including both massive flows, with recovered thicknesses of 1-8 m, and interlayered volcaniclastics. All the flow units have similar mineralogy with only minor variations in texture and phenocryst content. On the basis of their petrography and chemical compositions, we interpret them as nepheline-bearing alkalic basalts.

\section{Clasts From the Sedimentary Section}

Four basalt fragments, encompassing three distinct textural variants and presumably representing three separate flows, were recovered near 436 mbsf within the claystone weathering profile of lithologic Unit III. Their relationships to one another and to the rest of the sequence are unclear. The most likely explanation is that they represent fragments carried downslope as scree or stream-bed load.

\section{Volcanogenic Sandstones}

Two brick-red volcanogenic sandstones (Units 3 and 12) occurring within the upper part of the igneous basement have been completely altered to clays and iron oxyhydroxides. Unit 3 is graded and preserves a strong horizontal fabric, imparted both by sedimentary layering and by compaction of angular, vesicular volcanic clasts up to $1 \mathrm{~cm}$ in size. Unit 12 was broken up by drilling but a similar planar fabric is apparent.

\section{Volcanic Breccias}

Units 4-7 (452.8-457.8 mbsf) are poorly sorted basaltic breccias, varying widely in grain size $(2-20 \mathrm{~cm})$ and in the proportion of sandsized, volcanogenic matrix material present. The breccias are highly altered and too friable to permit detailed study, but the majority of clasts do not appear to have been highly vesicular. They do not appear to have been produced by explosive eruption. They most likely represent talus or other erosional debris.

\section{Major Basaltic Units}

Twelve basalt units that are continuous over a significant length of core were recovered in Hole 871C. Several small groups of angular basalt fragments, whose relationships to one another and to adjacent core could not be determined, were assigned unit numbers for logging purposes, but were not investigated further. Unit 1, recovered immediately beneath the lowermost claystone of lithologic Unit III, is a relatively thin $(50 \mathrm{~cm})$, medium-gray basalt, crisscrossed by a stockwork of $1-2-\mathrm{mm}$ calcite veins spaced about $5 \mathrm{~cm}$ apart. Distinct contacts and orientations are not preserved in the core and it is not known whether this unit is a flow or an intrusion. Like the majority of basalts at this site, it contains small (1-2 mm) phenocrysts of clinopyroxene in a microcrystalline groundmass. A notable feature of this unit is the presence of a number of small $(<4 \mathrm{~cm})$, highly altered, rusty brown xenoliths.

Beneath the breccia units, 11 distinct massive flows (Units 13 to 23) complete the basement section (Premoli Silva, Haggerty, Rack, et al., 1993). The upper eight flows (Units 13-20) are relatively thin, with recovered thicknesses between 1 and $4 \mathrm{~m}$. Beneath these are two thick flows (Units 21 and 22), each with a recovered thickness of 7.5 $\mathrm{m}$. The core recovered from each unit appears continuous and recovery through much of this interval was greater than $80 \%$ (Premoli Silva, Haggerty, Rack, et al., 1993, p. 44), so it is likely that the recovered intervals are probably close to the actual flow thicknesses.

Individual flow units are distinguished by changes in phenocryst content and/or in texture, or by the presence of intervening zones of broken and/or highly altered material. These broken zones do not, for the most part, appear to represent rubbly or weathered flow tops, and in no case was a distinct chilled margin or other flow margin feature recovered in Hole $871 \mathrm{C}$. However, a number of the thinner flows 
appear more vesicular near their tops. In the thicker flows near the bottom of the hole, zones of high vesicularity occur within the flow interiors but are not conspicuous near the margins.

All the basaltic units are very similar, differing only slightly in textural detail and in phenocryst abundances. The largest phenocrysts are invariably olivine, typically euhedral to rounded, 3-5 $\mathrm{mm}$ in size, and constitute $>5 \%$ of the lava. Sporadic larger, angular olivines appear to be xenocrysts related to small, olivine-rich xenoliths that occur sporadically throughout the section. Virtually all olivines are at least partially altered to rusty brown iddingsite margins with a variety of phyllosilicates and/or calcite in their interiors; fresh olivine is only sporadically present. Small (1-4 mm), dark green to black phenocrysts of clinopyroxene are almost ubiquitous and typically constitute $10 \%-20 \%$ of the lava. In thin section, they are seen to be bright pink titanaugite. They are commonly fresh, although alteration to a soft, green layer silicate, presumably chlorite, or to dark red-brown clay is also common.

\section{Alteration and Weathering Features}

The entire basaltic section has been pervasively, but patchily, altered, apparently by low-temperature hydrothermal processes. Alteration features are of three main types.

1. Veins of calcite are generally $1-2 \mathrm{~mm}$ thick, but ranging up to $8 \mathrm{~mm}$. They commonly include a light green phyllosilicate, which swells rapidly on exposure to air and/or fresh water; this is presumably a montmorillonite.

2. Vesicles are invariably filled with one or more of several minerals including calcite, montmorillonite (as above), dark green celadonite(?), and an unidentified white zeolite.

3. Basalt groundmass is patchily altered to a deep purplish brown. This type of alteration is ubiquitous in the matrices of the breccias and is also common in the lower basaltic units, where zones of continuous purplish alteration surround isolated, gray, less altered domains. In the latter case, the basalt has a distinctly mottled appearance that resembles, at first glance, some of the breccias higher in the section.

As a consequence of this alteration, much of the core, although it appeared fresh when first opened, deteriorated rapidly on exposure to air. Subsequent handling led to complete disintegration to irregular, friable fragments only a few millimeters in size. This degradation precludes any meaningful petrographic or analytical study of the primary features of the affected material. Fortunately, all of the major flow units retain some regions of relatively unaltered material suitable for further study. We speculate that this phenomenon is related to the presence of abundant (altered) feldspathoids within the groundmass of the lavas.

\section{Petrography}

Fifteen thin sections, representing most of the major flow units, were examined. All have very similar mineralogy with minor variations in texture and mineral proportions, particularly phenocryst abundance. The basaltic lavas are characterized by abundant olivine microphenocrysts, commonly around $15 \%$, set in a microcrystalline, titanaugite-rich groundmass. Plagioclase is present only as anhedral, poikilitic, or interstitial crystals in the groundmass, never as phenocrysts or euhedral groundmass laths.

In most thin sections, the groundmass is characterized by abundant prisms of titanaugite, abundant cubes of magnetite, and fine needles of apatite. Orange biotite is a rare, but ubiquitous, groundmass phase. Interstitial to, and commonly poikilitically enclosing, these minerals are irregular patches of plagioclase and/or a clear, low-relief, low-birefringent material. This material can be identified as nepheline by its negative, uniaxial optical character in some samples, but it appears partially cloudy and almost isotropic in most. We have tentatively identified this cloudy material as partially altered nepheline, although it may include some alkali feldspar, plagioclase, or even analcime.
Fresh plagioclase is present in a number of samples as both small interstitial patches and as larger (up to $0.5 \mathrm{~mm}$ ), optically continuous, poikilitic regions. It is sparsely twinned, but the few grains suitable for optical determination consistently yield values close to $\mathrm{An}_{35}$.

The textures of the lavas appear to vary with flow thickness. The thinner lavas (Units 9, 13, and 15) are very fine-grained with intersertal textures in which the characteristic titanaugite and magnetite are separated by an unresolvable, cloudy, colorless matrix, presumably dominated by partially altered plagioclase and/or nepheline. The thicker lavas (Units 21 and 22) are, by contrast, well crystallized and less fine-grained with intergranular textures.

Based on their mineralogy, we infer that these lavas are distinctly alkalic and most likely strongly undersaturated. If our identification of nepheline is correct, the majority are best termed basanites, as they contain modal nepheline and plagioclase. Some of the finer grained samples are basanitoids because their mineralogy is not resolvable, and a single clast (Section 144-871C-33R-1, 5-20 cm) from the claystone unit is a nephelinite because it lacks plagioclase.

\section{Summary}

Hole $871 \mathrm{C}$ records a series of events, beginning near the end of the eruptive life of the Limalok volcano. The first recorded events are a series of eruptions of alkali basalts, basanites, and nephelinites, forming at least eleven massive flows ranging from 1 to more than 7 $\mathrm{m}$ in thickness. The margins of these flow units are not preserved in the drill core, so it is not known whether they are submarine or subaerial. Low-temperature hydrothermal alteration has been pervasive throughout the lava sequence, possibly suggesting that magmatic activity continued in the vicinity for some time after the eruption of the sampled flows. These arguments may suggest that the igneous section of the core represents part of a constructional phase of the volcano, rather than a short-lived, low-volume, post-erosional phase. This interpretation contrasts with Hawaiian examples, in which undersaturated, xenolith-bearing lavas are much more typical of posterosional phases.

Angular volcanic breccias and a thick overlying sequence of dense, mottled claystone record a (long?) period of weathering and erosion of the volcanic pile which was most likely subaerial initially, but terminated under unequivocally marine conditions.

\section{Lo-En Guyot (Site 872)}

\section{General Setting}

Three holes were drilled at Site 872, near the center of Lo-En Guyot. In this region, the basement reflectors appear almost horizontal (Premoli Silva, Haggerty, Rack, et al., 1993) and a simple slope extrapolation from the edge of the guyot would suggest that at least several hundred meters of subaerial basalt were removed by erosion before the deposition of the overlying sediments. Small amounts of basalt were recovered in Holes $872 \mathrm{~A}$ and $872 \mathrm{C}$, whereas Hole $872 \mathrm{~B}$ penetrated $57.3 \mathrm{~m}$ into basalt, with approximately $40 \%$ recovery.

In each hole, the uppermost basalt unit is an alkali olivine basalt. Based on texture and mineralogy, Unit 1 from Hole 872A and Unit 5 from Hole 872B (the uppermost basalt unit) appear to be from the same flow, whereas Unit 1 from Hole $872 \mathrm{C}$ contains microphenocrysts of clinopyroxene and is likely to have been from a different flow. Beneath the olivine basalt, Hole $872 \mathrm{~B}$ recovered a series of basalt and hawaiite flows, some of which display thick, brecciated flow-tops and/or horizontal vesicle-rich bands, almost certainly indicating that they were erupted subaerially.

\section{Lithologic Descriptions}

\section{Holes $872 \mathrm{~A}$ and $872 \mathrm{C}$}

Basement recovery in Hole $872 \mathrm{~A}$ was only $29 \mathrm{~cm}$ of severely altered, brownish gray, aphyric basalt. The groundmass is completely 
altered to green and brown clay, but relict textures show abundant plagioclase $(>50 \%)$ with lesser granular olivine and abundant $(>15 \%)$ magnetite. We interpret this to have been an alkali olivine basalt.

Hole $872 \mathrm{C}$ recovered several pieces of basalt. They are essentially identical in appearance, aphyric, with a medium gray groundmass that is rather less altered than that of the Hole $872 \mathrm{~A}$ basalt. The groundmass is dominated by plagioclase $(\sim 70 \%)$ with subordinate olivine, titanaugite, minor magnetite and ilmenite. This basalt is distinct in texture and the mineralogy from the uppermost basalts in Holes $872 \mathrm{~A}$ and $872 \mathrm{~B}$.

\section{Hole $872 B$}

Volcanic basement in this hole is referred to as lithologic Unit IV (Premoli Silva, Haggerty, Rack, et al., 1993). The uppermost basalt flow is designated Unit 5, although it is in direct contact with sedimentary rocks of lithologic Unit III. This is because Units 1-4 are small bodies of sedimentary material trapped in cracks within Unit 5 (Premoli Silva, Haggerty, Rack, et al., 1993). Small basalt pebbles are also incorporated in sediments at the base of lithologic Unit III.

Unit 5 is represented by only $10 \mathrm{~cm}$ of core. It strongly resembles the alkali olivine basalt of Hole $872 \mathrm{~A}$, both in its primary mineralogy and in its state of alteration, and it is likely that the two holes have intersected the same flow. Hole $872 \mathrm{C}$, on the other hand, although it is only $75 \mathrm{~m}$ away, has clearly intersected a different flow and it is of interest to note that the sedimentary environment immediately overlying basaltic basement is also quite different (Premoli Silva, Haggerty, Rack, et al., 1993, p. 118).

Units 6-9 and 11-13 are individual flows ranging in recovered thickness between 0.25 and $2.5 \mathrm{~m}$. They lack flow-top breccias or other contact features. Units 10 and 14-18 are thicker flows, between 1.5 and $6.0 \mathrm{~m}$ in recovered thickness, and characterized by the presence of thick flow-top breccias that typically comprise $30 \%-50 \%$ of the recovered thickness. Sharp basalt/breccia contacts recovered between Units 14, 15, and 16 lack any sign of weathering.

Clasts in the flow-top breccias are subangular and highly irregular in shape. They are typically $1-10 \mathrm{~cm}$ across with sporadic larger clasts to $30 \mathrm{~cm}$. They occur in a matrix of highly altered, volcanogenic sand. Because of the alteration, exact clast-matrix relationships are difficult to discern. The textures appear to be consistent with a subaerial origin as small a'a flows, but autobrecciation in a submarine setting cannot be excluded. The massive portions of the flows are aphyric to sparsely clinopyroxene and olivine-phyric with microcrystalline groundmasses, and are also typically highly altered. Vesicles are abundant in all the flows, generally concentrated in subhorizontal bands that are distributed throughout the flow. This characteristic may also suggest a subaerial origin.

\section{Alteration and Weathering Features}

All of the Site 872 basalts are extensively altered. Mottling and discoloration of the basalt in shades of yellow, red, and greenish gray are widespread, and dark iron-staining is common along fractures in some units. This discoloration appears to reflect primarily alteration of the groundmass to clay minerals and, perhaps, chlorite. Calcite, brown clay, and the pinkish orange zeolite, chabazite, are abundant as infillings in numerous small veins and vesicles and in the matrix of the breccias.

\section{Petrography}

The Site 872 lavas are characterized by abundant groundmass plagioclase $(45 \%-70 \%)$, with a strong preferred orientation, and by abundant $(8 \%-25 \%)$ euhedral titanomagnetite microphenocrysts. Ilmenite needles are also present in some flows. In most flows, both plagioclase and a mafic phase were originally present in small amounts as phenocrysts and microphenocrysts, but they have been replaced almost entirely by colorless, green or brown clays. Much of the groundmass of each flow has also been replaced by clays. The low abundances of olivine and clinopyroxene, the apparent absence of orthopyroxene, and the preponderance of plagioclase and titanomagnetite suggest that these lavas are most likely alkali basalts and hawaiites.

\section{Summary}

Site 872 yielded a series of relatively thick (2-5 m recovered) flows that we interpret as alkali basalts and hawaiites. These massive flows with thick brecciated tops are most likely subaerial eruption products, but soil or weathering horizons, which would indicate subaerial exposure, were not recovered and a submarine origin cannot be entirely precluded. The uppermost basalts are directly overlain by marine pelagic sediments, and in Hole $872 \mathrm{~B}$ several generations of fossiliferous sediment, recording a complex erosional and depositional history, have infiltrated cracks in the basalt.

These alkalic lavas form a differentiated series that may be comparable to those of the alkalic cap (or final shield-building) stage of Hawaiian volcanism. Differentiated series of this type are typically associated with long-lived volcanism and a well developed magma system is probably required in order for the necessary differentiation to take place. For this reason, it seems likely that the lavas of Site 872 represent a relatively late stage in the construction of Lo-En volcano and that deep erosion has not occurred.

\section{Wodejebato Guyot (Sites 873-877)}

\section{General Setting}

Five sites were drilled on Wodejebato Guyot, which is morphologically more complex than either Limalok or Lo-En (Bergerson, this issue; Premoli Silva, Haggerty, Rack, et al., 1993). One site (873), is near the center of the guyot and there are two sites on each of the inner $(874,877)$ and outer $(875,876)$ perimeter ridges. The upper surface of the volcanogenic basement appears from seismic records to be nearly horizontal, but relatively steeply dipping reflectors are present within basement beneath all sites. Based on drilling results from Site 873 , the only site with significant basement penetration, we believe that these dipping reflectors are from a thick submarine volcaniclastic sequence that is overlain by a thin sequence of subaerial lava flows. This part of the guyot may, therefore, have been primarily constructed underwater, with only a brief period of emergence during the final stages of volcanic activity. In other words, the horizontal upper surface of the basement may be primarily constructional, not erosional, in origin. It may, for example, represent a broad coastal plain around a larger emergent volcano, similar to, though wider than, coastal plains to the northeast of Kilauea Volcano or to the east of the northern volcanoes on Isla Isabela in the Galapagos.

\section{Lithologic Descriptions}

\section{Site 873}

The volcanogenic basement recovered in Hole $873 \mathrm{~A}$ is divided into three lithologic units. A thick claystone unit (Unit IV) is a subaerial weathering profile developed on and from the underlying basaltic lava flows of lithologic Unit V. These flows overlie a sequence of volcanogenic debris-flow breccias (lithologic Unit VI) which have a drilled thickness of approximately $30 \mathrm{~m}$, but may be much thicker if, as we infer, they correlate with the dipping seismic reflectors.

The recovery of basalt lavas in Hole $873 \mathrm{~A}$ was poor, averaging only $6.3 \%$. Nevertheless, the recovered material represents eight texturally distinct flow units. Two relatively unaltered pieces of basalt (Unit 9), which were recovered within the underlying breccia, most likely represent a small dike related to the overlying flows. Most of the basaltic lavas are aphyric or sparsely phyric with scattered dark green pseudomorphs after olivine or clinopyroxene. All are dominated by groundmass plagioclase, occurring both as an interstitial phase and as abundant laths that show some degree of preferred orien- 
tation. Clinopyroxene is present as small equant prisms in the groundmass and as sparse microphenocrysts. In some cases, a weak pinkish coloration and strong dispersion suggest that this is titanaugite; in others, the clinopyroxene is pale green. Magnetite is abundant in all unaltered samples as well formed, widely dispersed cubes. Olivine is not identifiable in the groundmass, but sporadic iddingsitized microphenocrysts are present. Based primarily on their textures, the lavas are divided into four types.

1. Aphyric or sparsely microcrystalline lavas of Units 3,8 , and 9 , interpreted as alkali basalts. The lower part of Unit 8 contains about $10 \%$ remarkably fresh euhedral or broken clinopyroxene microphenocrysts.

2. Hawaiites of Units 1 and 4, in which a meshwork of feldspar laths makes up nearly $40 \%$ of the lava and which contain minor biotite.

3. Highly altered aphanitic lavas of Units 2 and 6 , which are altered to a dark purplish gray and contain sparse, elongate vesicles.

4. Scoriaceous basalt of Unit 7, which consists of a single piece with a dense basaltic core surrounded by vesicular basalt, almost certainly part of a pyroclastic bomb (Premoli Silva, Haggerty, Rack, et al., 1993, chapter 5, fig. 44). This sample provides the only solid evidence for subaerial eruption of these lavas.

In all the lavas, at least $20 \%$ of the matrix has been altered to pale green clay. In some places this clay clearly replaces clinopyroxene, but in most cases the original mineralogy is not discernible.

The volcanic breccias at the base of Hole 873A consist primarily of subangular to subrounded clasts of glassy, highly vesicular basalt with sparse plagioclase microphenocrysts, commonly with swallowtail terminations. The glassy basalts have all been completely altered either to opaque tachylite or, more commonly, to bright green clay. None of the primary igneous material is preserved. Between the clasts is a matrix that now consists almost entirely of bright green clay, within which the outlines of the original detritus are well preserved. In its original state, the breccia matrix consisted entirely of highly angular glass shards and fine, broken fragments of glassy basalt. These fragile materials were clearly not exposed to a weathering environment before deposition and they can only have been transported by some form of mass flow. We interpret these deposits as hyaloclastite debris flows derived either from phreatomagmatic eruptions or, perhaps more likely, from the fragmentation of active lava flows in a submarine environment (submarine flows or subaerial flows entering the sea). Some reworking of the upper parts of individual debris flows has led to the formation of narrow, laminated or graded intervals (Premoli Silva, Haggerty, Rack, et al., 1993). The uppermost 3-4 m of the breccia is discolored to various shades of red and brown, in contrast to the deeper sections, which are dark green to black. This discoloration is important, as it suggests that the breccias were exposed to subaerial weathering before the overlying lava flows were emplaced.

\section{Sites 874 and 877}

Sites 874 and 877 are on the inner of two perimeter ridges near the northern edge of Wodejebato Guyot. Hole 874B passes from the overlying limestones, through approximately $15 \mathrm{~m}$ of dense claystone (lithologic Unit III) and penetrates $16 \mathrm{~m}$ into a single ankaramite flow (lithologic Unit IV). The lower part of the claystone retains the relict texture of the underlying ankaramite, clearly visible within the core. The upper part preserves the relict texture of a vesicular, plagioclasephyric basalt, identical in texture to the basalt from nearby Hole $875 \mathrm{C}$, on the outer perimeter ridge. The claystone is clearly a thick, subaerial weathering profile developed in situ, from the underlying basaltic flows. Hole $877 \mathrm{~A}$ passes through approximately $4 \mathrm{~m}$ of claystone into basalt breccia (lithologic Unit V). Again, the claystone clearly retains the relict texture of the underlying material.

The ankaramite recovered at the base of Hole $874 \mathrm{~B}$ appears to be from a single flow. It is highly porphyritic, containing abundant olivine and lesser clinopyroxene and plagioclase phenocrysts. Near the top of the drilled interval, olivine and plagioclase are completely replaced by iddingsite and clay minerals, but they become progressively fresher with depth. Clinopyroxene is largely unaltered throughout, and optically continuous, skeletal quench-overgrowths are common. Glomerocrysts are also common and some single large clinopyroxene grains enclose several smaller olivines. Some clinopyroxene grains are irregularly embayed and consist of small regions of contrasting color, which suggests that they are xenocrysts that were not in equilibrium with their host liquid. The matrix of the ankaramite is a microcrystalline alkali olivine basalt, dominated by granular pink titanaugite and plagioclase laths, with up to $10 \%$ euhedral titanomagnetite cubes and minor olivine. Olivine is completely altered to orange clay and plagioclase to green clay and zeolites in the upper part of the hole, but becomes fresher with depth, and some patches have remarkably fresh, clear phenocrysts. Patchy green and brown clay is abundant throughout the groundmass.

At about $185 \mathrm{mbsf}$, the ankaramite of Hole $874 \mathrm{~B}$ is traversed by a large $(\sim 1 \mathrm{~cm})$, nearly vertical, low-temperature hydrothermal vein with an alteration halo extending $3-5 \mathrm{~cm}$ on either side. The vein is lined by sparry calcite and filled with an unidentified, soft, greenish yellow clay mineral. Adjacent to the vein, the basalt matrix and olivine phenocrysts display a progressive color zonation in shades of green and red, respectively. The presence of this vein is significant because hydrothermal activity implies proximity to a magmatic heat source, either a volcanic center or, perhaps, an active rift zone.

The volcaniclastic breccia of Hole 877A resembles that of Site 873, with subrounded clasts (up to $3 \mathrm{~cm}$ ) of vesicular basalt and a predominantly glassy, fragmental matrix. The entire breccia has been largely altered to clay, and clast outlines are commonly difficult to distinguish. In thin section, the clasts can be seen to contain minor $(<3 \%)$ pale green clinopyroxene microphenocrysts with skeletal quench overgrowths and up to $15 \%$ small $(<2 \mathrm{~mm})$, broken or rounded, prismatic plagioclase grains. Clinopyroxene and plagioclase commonly occur together as glomerocrysts and they are interpreted as xenocrysts. The groundmass contains up to $30 \%$ swallowtail plagioclase in a highly altered, originally glassy, matrix.

\section{Sites 875 and 876}

Sites 875 and 876 are located on the outer perimeter ridge near the northern edge of Wodejebato Guyot and close to Sites 874 and 877 , respectively. Holes $875 \mathrm{C}$ and $876 \mathrm{~A}$ both pass from limestone into basaltic basement, with little or no indication of an intervening weathering horizon, in marked contrast to the thick clay weathering profiles drilled closer to the center of the guyot, at Sites 873, 874, and 877. In both holes, several altered, subangular to subrounded basalt pebbles were recovered at the limestone/basalt interface. Hole $875 \mathrm{C}$ extends for approximately $9 \mathrm{~m}$ into basalt, but less than $1 \mathrm{~m}$ of vesicular, alkalic basalt from a single flow unit was recovered. Hole $876 \mathrm{~A}$ extends for $14.5 \mathrm{~m}$, and approximately $2.2 \mathrm{~m}$ of basalt was recovered from three distinct flows.

The Hole $875 \mathrm{C}$ basalt is highly vesicular with numerous, relatively coarse-grained $(0.5-2 \mathrm{~mm})$ plagioclase laths and prisms visible in hand specimen. It is friable to the touch, predominantly gray in color, with areas of brownish or greenish discoloration. These characteristics reflect a significant degree of alteration. Its fabric strongly resembles the relict basaltic fabric preserved in the upper part of the claystone layer of Hole 874, suggesting that the same flow, or a series of closely related flows, is present at both sites. This correlation is important for our understanding of the origin of the inner and outer ridges (Premoli Silva, Haggerty, Rack, et al., 1993; Bergerson, this volume). If the correlation is valid, it implies that there was a continuous surface between the present sites of the two ridges at the time of basalt emplacement. The basalt on the outer ridge is now $15-20 \mathrm{~m}$ deeper relative to sea level than that on the inner ridge (Premoli Silva, Haggerty, Rack, et al., 1993), but we cannot tell whether this differ- 
ence reflects the topography that was present at the time of deposition or whether it reflects later subsidence of the outer ridge.

The primary mineralogy of the Site 875 basalt appears to have been that of an alkali olivine basalt. It is dominated by dense clusters of relatively coarse-grained plagioclase laths and prisms; much of the plagioclase has been altered to cloudy, colorless clay. Olivine was present both as phenocrysts $(\sim 15 \%)$ and in the groundmass $(\sim 5 \%)$ but it is now completely altered to green-brown clay. As with the great majority of lavas from the other Wodejebato sites, well formed magnetite grains make up a significant proportion of the lava and appear to have formed fairly early in the crystallization sequence.

Hole 876A encountered three texturally distinct basalt flows (Units 1,3, and 4). Part of the flow top breccia of Unit 3 (designated Unit 2) was also recovered. Units 1 and 3 are very fine-grained alkali basalts with sparse microphenocrysts of clinopyroxene and olivine. They are moderately altered, as reflected in the brownish and greenish discoloration of the matrix. Both basalts have intersertal to pilotaxitic textures, dominated by plagioclase, with interstitial clinopyroxene and relatively abundant, well crystallized magnetite. In Unit 1, plagioclase is completely altered to colorless or light brown clay, but in Unit 3, the plagioclase remains remarkably unaltered. Both samples contain 5\%$10 \%$ interstitial green clay, some of which appears to have replaced the original groundmass olivine. The flow top breccia of Unit 3 has a recovered thickness of about $1 \mathrm{~m}$. The breccia is friable, reflecting extensive alteration to clay, and it has been oxidized to predominantly dark red colors. The primary structure of the breccia is, however, clearly preserved. The clasts are subangular to subrounded basalt fragments, variable in texture and vesicularity. In thin section, they appear almost opaque owing to the pervasive alteration, but a very fine-grained, well crystallized, pilotaxitic to intersertal texture, identical to that of Unit 3, can still be distinguished. About half of the void space appears to have contained finely broken basalt fragments that have since been altered to brown clay. The remaining void space, now filled by an equigranular mosaic of well crystallized calcite and the zeolite chabazite appears to have originally been empty. These characteristics are quite distinct from the hyaloclastic breccias of Site 873. At the base of Hole $876 \mathrm{~A}$, a relatively coarse-grained alkali basalt (Unit 4) is represented by a single piece of core. It is a plagioclase microphyric lava, dominated by up to $20 \%$ plagioclase forming glomerophyric aggregates of relatively large $(\sim 1 \mathrm{~mm})$ laths and by striking glomerocrysts of smaller $(0.2-0.5 \mathrm{~mm})$, anhedral titanaugite grains with minor (altered) olivine.

\section{Summary}

Volcanogenic materials recovered from the five Wodejebato sites record the passage from submarine construction through subaerial construction and weathering to the erosion and foundering of the volcanic edifice from which this guyot has evolved.

Submarine or phreatomagmatic, nearshore eruption of vesicular basalts of unknown chemical affinity led to the rapid formation of hyaloclastite debris flows with some minor reworking. Continued activity of this type could have led to extensive outbuilding of the volcanic edifice, a probable explanation for the outward-dipping seismic reflectors that characterize the basement of this and other guyots, including both Lo-En and Limalok.

Weathering occurred in an oxidative (subaerial) environment for sufficient time to oxidize at least the upper $5 \mathrm{~m}$ of hyaloclastic material at Site 873.

A series of differentiated (olivine poor) alkalic basalt and hawaiite flows was erupted, most likely in a subaerial environment. These lavas are texturally distinct from those which produced the hyaloclastites.

Toward the center of the guyot and at the site of the present inner perimeter ridge, the basalts were exposed subaerially for sufficient time to produce a clay-rich, in situ weathering profile at least $20 \mathrm{~m}$ thick. Such extensive weathering is not recorded at the outer perimeter ridge sites.

A transition to marine conditions occurred in a protected environment at the three inner sites, but the absence of a weathering profile and the presence of basalt pebbles in the lowermost marine sediments implies higher energy conditions at the outer sites.

Insofar as they overlie the breccias, the lavas from the Wodejebato sites are literally "post-erosional," but it is not known whether they represent a distinctly different eruptive phase from the eruptions that gave rise to the hyaloclastites. They most likely represent the last volcanic episode at these sites, and they may represent the waning stages of volcanism on the edifice as a whole. This interpretation is consistent with the alkalic nature of the lavas and with the morphology of the basement of the guyot as seen in the seismic records. If this interpretation is correct, it implies that, in this case, the nearly horizontal upper surface of the basement is primarily a constructional feature. There is, however, one potentially significant problem with this interpretation. The presence, within the ankaramite of Site 874, of a single vein of apparent hydrothermal origin, raises some important questions. Does this vein require the presence of an active hydrothermal system? If so, is a nearby, relatively long-lived magmatic system required? Can such a vein form within a few meters or tens of meters of the surface, or is much thicker overburden required? These questions cannot be resolved using the available data.

\section{MIT Guyot (Site 878)}

\section{General Setting}

MIT Guyot has an unusually elongate shape and a relatively complex seismic stratigraphy (Premoli Silva, Haggerty, Rack, et al., 1993), suggesting that its volcanic substructure may have been unusually complex or that it has been extensively modified by later slumping or other events. Site 878 is situated just inside the southern perimeter ridge of the guyot. Beneath this area, shallow, landward-dipping seismic reflectors intersect the more nearly horizontal sediment reflectors of the central part of the guyot and mask a sub-horizontal basement reflector that is apparent to the north.

Two lithologic units of volcanic origin were drilled in Hole 878A. A thick, polymict, volcanogenic, basalt-limestone breccia (lithologic Unit IV), interpreted as phreatomagmatic in origin, is separated by platform limestones of lithologic Unit V from basaltic basement. The basement section (lithologic Unit VI) includes 24 alkalic lava flows and several volcaniclastic units. The 24 flows represent three distinct intervals of volcanism separated by periods of weathering, and they include seven distinct petrographic types. Lava flows of the three volcanic intervals are separated by altered and oxidized volcaniclastic materials. An oxidized flow-top breccia was recovered with almost every massive flow, suggesting that the entire sequence is subaerial. All the igneous units have been considerably altered, resulting in replacement of both matrix and phenocrysts by clay. Deep in the section, extensive bleaching of some altered breccias and minor serpentinite slickensides suggest that there may have been limited low temperature hydrothermal circulation.

\section{Lithologic Descriptions}

\section{Polymict Volcanogenic Breccias}

Polymict basalt-limestone breccia containing both basalt and limestone clasts in a white to grayish green, sand-sized matrix was recovered between 401 and 604 mbsf. The breccia can be divided into two major cycles that grade from carbonate-rich at the base to basalt-rich at the top. Each cycle most likely represents a short-lived eruptive episode from a single vent. At the beginning of each cycle, the eruptive products were dominated by preexisting (accidental) basalt and limestone fragments. As the vent became established, progressively more juvenile material (i.e., derived from new lava) was incorporated into the eruptive products. Virtually all the basalt clasts have been completely replaced by clay minerals, but they retain well-preserved relict igneous textures. The clasts are principally of two types, highly vesicular scoriaceous basalt, interpreted as juvenile material, and microcrys- 
talline, sometimes olivine microphyric basalt, interpreted as accidental inclusions of basement lava. A variety of minor basalt clast types are presumably also of accidental origin. In parts of the section, oversteepened bedding (up to $60^{\circ}$ ) and a few curved or overturned beds imply deposition on a steep slope and subsequent slumping.

We interpret these breccias as the result of short-lived, very late stage, phreatomagmatic eruptions through a carbonate platform. The resulting mixed basalt-limestone debris was redeposited very rapidly by gravity flows down a steep slope, either constructional or created by down-faulting at the outer edge of the platform.

\section{Major Basaltic Units}

Volcanic basement was first encountered at $722 \mathrm{mbsf}$ and drilling continued for $187 \mathrm{~m}$ through at least 24 distinct lava flows with several intercalated basaltic breccias and finer grained volcaniclastic units. Almost all the lava flows appear to be subaerial in origin with well defined vesicular and/or brecciated flow tops that grade downward into massive basalt. The flow tops are all altered to reddish or purplish colors and substantially replaced by clay, but they do not appear to have undergone significant weathering.

Interbedded with the flows are a number of volcaniclastic units including three breccia units, three finer grained tuffs, and several other units for which there was very little recovery. Two of the breccias are about $1 \mathrm{~m}$ thick, whereas the third (and lowermost) is about $15 \mathrm{~m}$ thick. They consist of poorly sorted, angular to subrounded clasts in a highly altered matrix and their exact mode of origin is uncertain. The fine-grained volcaniclastic units are completely altered to clay minerals, but relict textures are well preserved and their origins can be readily inferred. They include two water-laid basaltic tuffs composed of poorly sorted vesicular and nonvesicular basalt fragments and a thick $(15 \mathrm{~m})$, highly altered vitric tuff, originally composed of angular, vesicular glassy clasts in a glassy matrix.

The 24 flows represent at least three distinct periods of volcanism separated by significant weathering horizons. The upper volcanic interval consists of two hawaiite flows underlain by volcaniclastic breccias and tuffs. The middle volcanic interval consists of seven basanitoid flows and a thick breccia deposit. Below the basanitoids, a thick claystone weathering profile retains relict textures of basalt and basalt breccia. The lower volcanic interval contains 15 flows and one thick breccia deposit. The upper three flows of this sequence are also basanitoids, and the remainder are alkali olivine basalts.

\section{Alteration and Weathering Features}

All the igneous units have been considerably altered, resulting in replacement of both matrix and phenocrysts by clay. This is particularly true of the flow tops, which are typically reddish or purplish in color and substantially replaced by clay, although, in most cases, the flow tops do not appear to have undergone significant weathering. Vesicles are filled by white or pale to dark green clay. This type of alteration must have occurred at low temperatures.

In contrast, the thick, lowermost volcanic breccia is severely altered, with an upper, bleached subunit and a lower, oxidized subunit. The vitric tuff unit in the upper weathering interval has also been severely bleached to a light beige, soapy clay. This type of bleaching appears to be the result of low-temperature hydrothermal alteration. Serpentine slickensides that occur on two steeply dipping $\left(70^{\circ}\right)$ fractures close to the bottom of the hole may also reflect a relatively high-temperature hydrothermal process. Finally, it should be noted that Site 878 is the only Leg 144 site with significant basalt recovery where calcite veins are not prevalent throughout the basaltic section.

\section{Petrography}

The 24 lava flows of Hole $878 \mathrm{~A}$ can be divided into seven types on the basis of their petrographic characteristics. Individual petrographic descriptions are available in Premoli Silva, Haggerty, Rack, et al. (1993).
Type 1 lavas are interpreted as hawaiites, primarily on the basis of their textures and mineralogy. They are characterized by moderately abundant plagioclase, olivine, and clinopyroxene phenocrysts. Olivine microphenocrysts are abundant $(5 \%-10 \%)$ in a groundmass dominated by weakly flow-oriented plagioclase laths and accompanied by greenish, granular, clinopyroxene, anhedral, magnetite, and interstitial plagioclase with minor acicular apatite and tiny, bladed ilmenite. Most of the phenocrysts and much of the groundmass plagioclase have been replaced by clay minerals.

Type 2 lavas are basanitoids, characterized by their fine grain size, intergranular texture, and a predominance of matrix titanaugite. They contain abundant (5\%-20\%) olivine microphenocrysts ranging from larger $(\sim 1 \mathrm{~mm})$, euhedral shapes to smaller $(>0.2 \mathrm{~mm})$, anhedral, apparently broken grains set in an intergranular matrix dominated by clusters of subhedral, pink titanaugite. In some flows, a few large, broken, and partially resorbed prisms of clinopyroxene and/or plagioclase are also present. Other groundmass phases include plagioclase laths, colorless interstitial patches that were originally plagioclase and/or nepheline, and abundant $(\sim 10 \%)$ magnetite cubes. Green clay has replaced the original mesostasis, and colorless clay or zeolite with mottled extinction and low birefringence has replaced some of the interstitial feldspar.

Type 3 lavas are basanitoids differing from those of type 2 in the predominance of plagioclase over titanaugite and the finer grain size and greater abundance of groundmass titanomagnetite. A 10 -m-thick breccia of type 3 basanitoid clasts (Unit 12), lies between two type 2 lava flows.

Type 4 alkali basalts are characterized by sparse olivine, clinopyroxene, and plagioclase phenocrysts in an intersertal groundmass dominated by plagioclase and containing sporadic small biotites. Type 4 lavas contain up to $15 \%$ olivine and sparse $(<5 \%)$ phenocrysts of plagioclase and clinopyroxene. The groundmass is intersertal, dominated by laths and interstitial patches of plagioclase with granular olivine (replaced by green/brown clay), titanaugite, and subhedral to anhedral bladed or granular ilmenite. Apatite needles are abundant. Orange biotite flakes occur sparsely throughout. Green clay has replaced the mesostasis, and colorless clay or zeolite, with mottled, low birefringence, has replaced some of the feldspar.

Type 5 alkali basalts are characterized by a distinctive intersertal texture dominated by randomly oriented, bladed ilmenite in a matrix of plagioclase laths and lesser, granular titanaugite. Olivine, the sole phenocryst phase, occurs in two distinct size ranges. Larger (1-3 mm), subhedral, partially resorbed xenocrysts of olivine make up approximately $1 \%$ of the lava, whereas much smaller $(0.05-0.2 \mathrm{~mm})$ anhedral grains make up as much as $10 \%$. The groundmass is dominated by plagioclase laths and bladed ilmenite grains forming a randomly oriented meshwork. Within this meshwork, granular titanaugite, interstitial plagioclase (and/or alkali feldspar), pale green clay (replacing mesostasis), and traces of biotite and apatite also occur.

Type 6 alkali basalts are characterized by abundant $(15 \%-20 \%)$, fine-grained, granular oxide minerals distributed in varying proportions to produce flow-banded or irregular dark/light color variations in hand specimen. They are very fine-grained, with unusually abundant ( $1 \%)$ biotite plates and sparse $(5 \%)$ olivine microphenocrysts set in an intergranular matrix dominated by abundant (15\%-20\%) fine, granular ilmenite, plagioclase laths and granular titanaugite with minor green/brown clay replacing mesostasis. A weak lamination may be created by concentrations of larger plagioclase laths into narrow, poorly defined, flow-bands.

Type 7 alkali olivine basalts are characterized by abundant olivine phenocrysts in an intergranular groundmass dominated by plagioclase. This type includes only the deepest drilled flow. Sparse clinopyroxene grains, intergrown with plagioclase, can be seen in hand specimen, but have not been observed in thin section. Olivine (3\%) phenocrysts range in size from $3 \mathrm{~mm}$ to less than $0.5 \mathrm{~mm}$. The larger phenocrysts have rounded, anhedral shapes and are largely fresh. Smaller grains and rims of larger grains are replaced by green/brown clay. The groundmass is 
dominated by laths and interstitial patches of plagioclase, with lesser green, subhedral clinopyroxene $(\sim 10 \%)$, magnetite cubes $(10 \%)$, and traces of apatite.

\section{Summary}

Hole $878 \mathrm{~A}$ was terminated almost $200 \mathrm{~m}$ into the basaltic basement of MIT Guyot, by far the deepest penetration of Leg 144. The lavas recovered, including basanites, alkali olivine basalts and hawaiites, constitute a differentiated suite of alkalic affinity. Such a differentiated suite is, perhaps, more likely to be associated with a well established magmatic system, representing part of a constructional phase of volcanism, than with a later rejuvenated phase. They are broadly analogous to the upper shield or alkalic-cap phase of Hawaiian volcanism, although basanitic lavas appear to be much more abundant at MIT Guyot. Given that SOPITA lavas are, in general, more alkalic than Hawaiian lavas, it is possible that, in any specific volcanic stage, more alkalic lava types such as basanites may appear. By contrast, the explosive eruptions that formed the polymict breccia may represent a posterosional stage of volcanism, because a significant amount of time must have elapsed while MIT Guyot subsided and developed a carbonate platform. Well known, but imperfect, modern analogs for this type of eruption are the Honolulu series tuff cones of Oahu, such as Diamond Head and Salt Lake Crater. The tuffs at these localities are analogous in terms of their polymict character, but they are much finer-grained and they were deposited subaerially.

\section{Takuyo-Daisan Guyot (Site 879)}

\section{General Setting}

Site 879 was drilled on a perimeter ridge near the southern edge of Takuyo-Daisan Guyot. Seismic records show that the basement beneath this site is fairly shallow and that it slopes gently upward toward a central volcanic high. A prograding sequence of reflectors that dip away from this high within the basement are interpreted as a volcaniclastic sequence similar to that in the Wodejebato drillholes.

Hole $879 \mathrm{~A}$ passes, at approximately $265 \mathrm{mbsf}$, from the pebble conglomerate of lithologic Unit II into a complex, intercalated mixture of basalt and volcanic breccia (lithologic Unit III). This mixture is a peperite, formed by the intrusion of basaltic lava into soft, wet sediment, in this case a volcanogenic breccia. Drilling was terminated about $20 \mathrm{~m}$ into this material.

\section{Lithologic Descriptions}

Basalt

Plagioclase-phyric basalt occurs throughout the basement interval as irregular, subspherical, pillow-like bodies, ranging in size from less than a centimeter to a meter or more. Narrow relict chilled margins can be recognized by subtle variations in color and texture adjacent to many of the pillow surfaces. Plagioclase, which constitutes approximately $20 \%$ of the basalt, occurs as subhedral, rather elongate prisms (seen to be glomerocrysts in thin section), ranging in length from about 0.5 to $8.0 \mathrm{~mm}$. In the fresher parts of the basalt, the phenocrysts are transparent and remarkably fresh, but for the most part they are partially altered to white clay or zeolite and are commonly stained red or green. Sparse $(1 \%)$, euhedral, diamond-shaped olivine microphenocrysts, completely altered to reddish brown iddingsite, occur throughout. The matrix of the basalt appears microcrystalline, medium gray in fresh pillow centers, but slightly reddish elsewhere, reflecting pervasive alteration.

\section{Volcanogenic Breccia}

The irregularly shaped spaces between the basalt pillows are occupied by grayish green volcanogenic breccia. The components of the breccia have been completely replaced by soft clay and/or zeolite min- erals, but primary textural features are retained in great detail. About $60 \%$ of the original clasts were fragile, angular, highly vesicular, glassy basalt. The remaining clasts were also angular and they included a variety of nonvesicular basalts. Very little of the interpillow material has been formed by fragmentation of the associated plagioclase phyric lava, although numerous, rounded "mini-pillows" are common. Angular fragments of the intrusive basalt do occur, but they are restricted to areas of autobrecciation where localized fracturing of pillow margins has occurred. The matrix of the breccia consists of sand-sized shards of the same glassy, vesicular basalt as the larger clasts, cemented by grayish green clay or zeolite. In one $20-\mathrm{cm}$ interval, well-sorted, coarse volcanogenic sandstone fills the interpillow spaces.

This breccia is very similar in texture and in mode of emplacement to the polymict breccias of Hole 878A. In this case, however, the dominant clasts are juvenile vesicular basalt, presumably formed by fragmentation of new magma. Accidental clasts formed by explosive fragmentation of preexisting basalt are also present.

\section{Alteration and Weathering Features}

Both basalt and breccia are pervasively altered and variably discolored in red and green shades. This discoloration reflects pervasive alteration to clay and zeolite minerals which is essentially complete in the breccias. Calcite veins are common throughout the basaltic section. Most are less than a few millimeters thick with scattered veins up to 1 $\mathrm{cm}$. Adjoining the veins are distinct, banded alteration fronts, visible as variations in the extent of reddish discoloration of the groundmass and phenocrysts. Pillow margins themselves are also marked by narrow (1-2 mm) color bands in shades of red and brown, in addition to the gradation from microcrystalline through glassy textures.

\section{Petrography}

In thin section, the basalt of Site 879 is seen to contain $20 \%-30 \%$ complex plagioclase crystal aggregates ranging in size up to $5 \mathrm{~mm}$. A typical aggregate consists of several, generally equally sized, prismatic, zoned crystals. These are commonly broken or embayed, and they contain abundant melt inclusions. Although these plagioclases appear to be xenocrystal in origin, their compositions overlap those of plagioclase in the groundmass (Dieu, this volume), suggesting that they may have originated by a complex crystallization path from the magma in which they occur. The predominant groundmass phase is about $20 \%$ randomly oriented plagioclase laths with about $10 \%$ granular, greenish clinopyroxene and about $10 \%$ iddingsite in granular pseudomorphs after olivine. The remaining mesostasis has been completely altered to mottled clays. Based on the abundance and textural characteristics of plagioclase and the relative paucity of groundmass olivine we tentatively suggest that this is a transitional or even tholeiitic basalt. This suggestion is also supported by aspects of the clinopyroxene chemistry (see later section and Dieu, this volume).

\section{Summary}

The materials in the breccia are derived from a phreatomagmatic volcanic eruption, which predates and is separate from the intrusion of the plagioclase-phyric basalt. The time period between these two volcanic events is not constrained, but probably was relatively short, as the intruded sediments were necessarily water-saturated with a low bulk density. None of the observed features of the glassy basalt clasts in the breccia provide any indication of their petrologic affinities. The basalt is inferred on the basis of its plagioclase-phyric character and low matrix olivine to be of transitional or mildly alkalic affinity. (Mineral compositions and rare earth element abundance patterns support this conclusion-see later section) The eruptions sampled at this site must have occurred relatively late in the history of the volcano, but their geological context is very poorly constrained by the available data. 


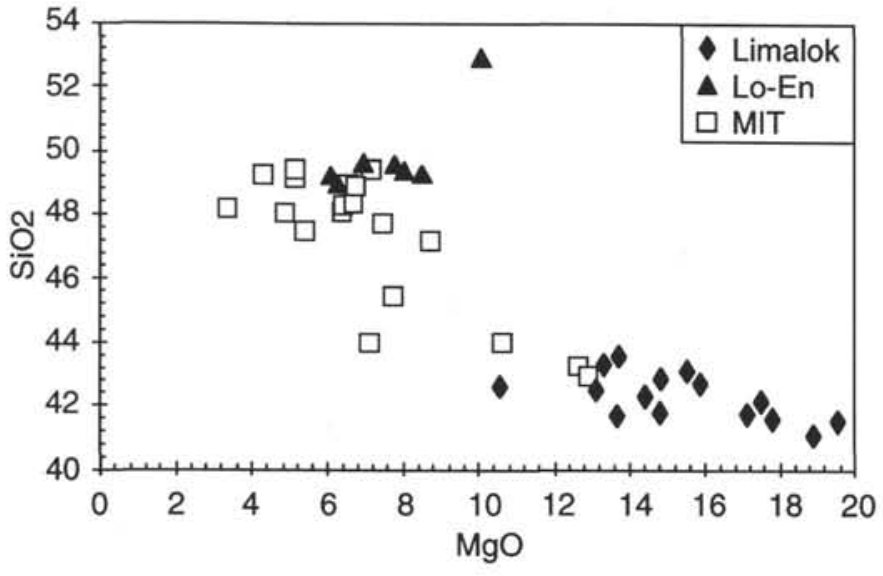

Figure 1. $\mathrm{MgO}-\mathrm{SiO}_{2}$ variation diagram for $\mathrm{Leg} 144$ lavas.

\section{MAJOR ELEMENT CHEMISTRY}

Major element analyses of representative samples from Limalok, Lo-En, and MIT guyots are listed in Table 1. Usable major element data are not available for the phenocryst-rich basalt of Site 879 or for the highly altered, clay-rich lavas of Wodejebato (Sites 873-877). Consistent with the pervasive alteration of virtually all Leg 144 lavas, losson-ignition (LOI) values are variable and high (up to $8 \mathrm{wt} \%$ ). Even the freshest Lo-En and Limalok lavas have LOI values of about $2 \mathrm{wt} \%$ and only two MIT samples, from deep in Hole 878, have values below 1 $\mathrm{wt} \%$. The most obvious alteration effects in the major element data are low $\mathrm{Na}_{2} \mathrm{O}(<1 \mathrm{wt} \%)$ and $\mathrm{K}_{2} \mathrm{O}(<0.3 \mathrm{wt} \%)$ values for most of the highLOI Limalok basanites. In fact, all the Limalok lavas have lower alkali contents than one might expect for fresh basanitic lavas, and the loss of $\mathrm{K}_{2} \mathrm{O}$ is confirmed when $\mathrm{K}$ values are compared to the abundances of certain trace elements (see next section). Phosphorus addition, a common problem for dredged lavas as a result of phosphorite deposition, is not apparent in these drilled samples, which have not been directly exposed to upwelling seawater.

The lavas cover a wide range of compositions, with $\mathrm{MgO}$ ranging from almost $20 \mathrm{wt} \%$ to as low as $3 \mathrm{wt} \%$ and $\mathrm{SiO}_{2}$ from about 41 to 50 $\mathrm{wt} \%$, with a single Lo-En sample having $53 \mathrm{wt} \% \mathrm{SiO}_{2}$ (Fig. 1). The basanites of Limalok Guyot extend to very high $\mathrm{MgO}$ contents, much greater than those of typical Samoan basanites $(\sim 10-15 \mathrm{wt} \%$; Wright, 1986), which presumably reflects incorporation of olivine from the abundant xenoliths and xenocrysts that occur throughout this unit. It is also possible that there has been some redistribution of $\mathrm{MgO}$ at individual sites as a result of alteration. This is suggested by the observation that a number of immobile trace and minor elements do not vary systematically with $\mathrm{MgO}$ at some sites. This possibility is discussed more fully in the following section.

Even though there has been some alkali loss, alkali-silica relationships (Fig. 2) generally confirm the rock identifications and the alkalic affinities inferred from petrographic observation. With the exception of three low-K Limalok samples and two evolved Lo-En hawaiites, all the analyzed lavas lie above the classic line of Macdonald and Katsura (1964) that separates the fields of Hawaiian alkalic and tholeiitic lavas. Compared with basanites from Hawaii and Samoa (Fig. 2), the Limalok lavas have rather low alkali contents, further suggesting that there has been significant loss of alkalies from all these lavas, presumably as a result of the alteration of groundmass nepheline. Note that the lavas from MIT Guyot vary widely in $\mathrm{SiO}_{2}$ content and that they appear to define a shallow crystal fractionation trend.

\section{TRACE ELEMENT CHEMISTRY}

Trace element analyses of representative samples from all sites (Tables 2,3) were determined by XRF and ICP-MS techniques. Here

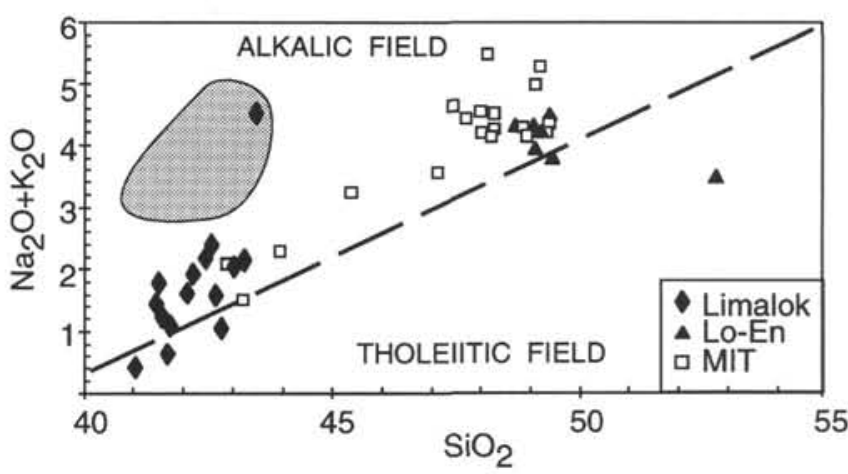

Figure 2. Alkali-silica diagram of Macdonald and Katsura (1964) showing data for Leg 144 lavas. The field of Samoan basanites (shaded) is shown for comparison (data of Wright, 1986).

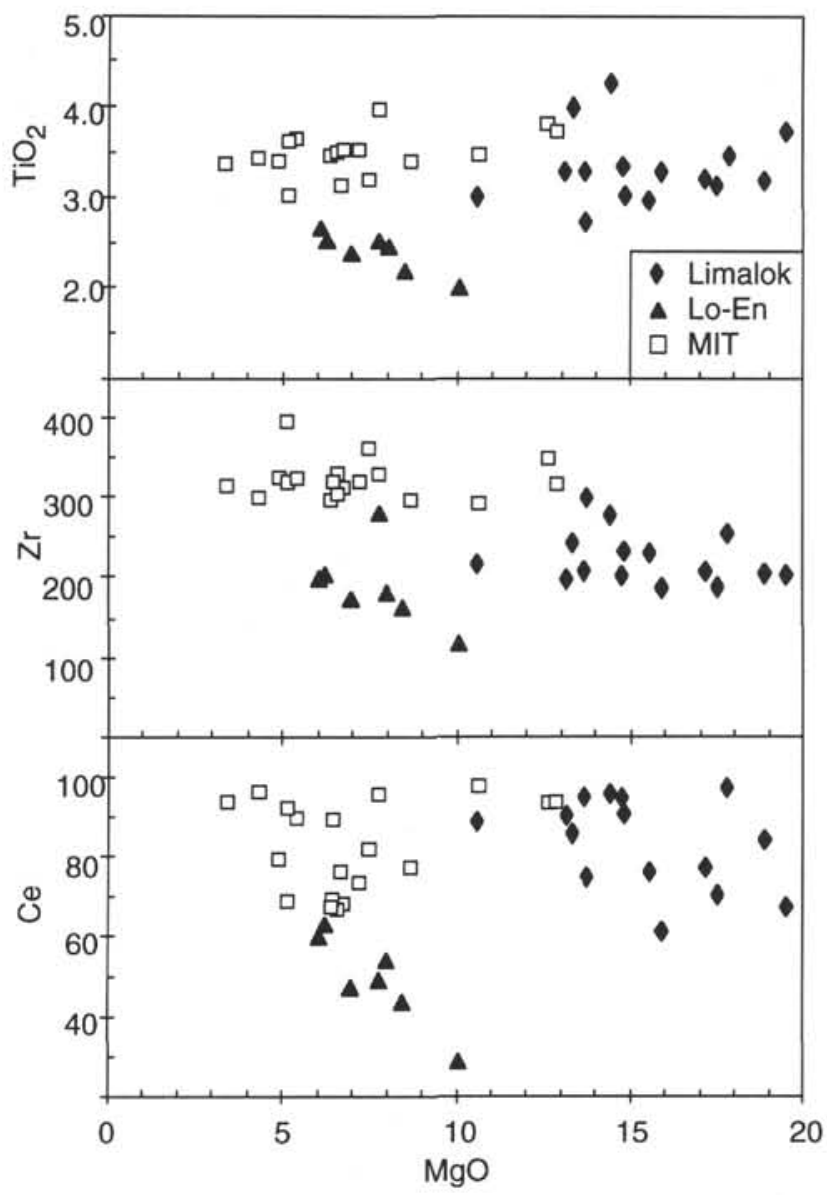

Figure $3 . \mathrm{MgO}$ variation diagrams for selected incompatible trace elements. Note the general lack of systematic variation for lavas of Sites 871 (Limalok) and 878 (MIT) and the apparent fractionation trend for Site 872 (Lo-En).

we discuss the variability of the more incompatible elements in order to characterize the mantle source regions for Leg 144 lavas and allow for comparisons to lavas from present-day SOPITA volcanoes.

\section{Variability with $\mathrm{MgO}$}

The more incompatible (and immobile) minor and trace elements (including $\mathrm{Ti}, \mathrm{P}, \mathrm{Zr}, \mathrm{Ba}, \mathrm{Ce}$, and $\mathrm{Y}$ ) fall into three distinct groups when plotted in $\mathrm{MgO}$ variation diagrams (Fig. 3). The basanites of Limalok 
Table 1. Major element data by XRF.

\begin{tabular}{|c|c|c|c|c|c|c|c|c|c|c|c|c|c|c|}
\hline $\begin{array}{l}\text { Core, section, } \\
\text { interval }(\mathrm{cm})\end{array}$ & $\begin{array}{c}\text { Igneous } \\
\text { unit }\end{array}$ & $\begin{array}{l}\text { Petrographic } \\
\text { type }\end{array}$ & $\mathrm{SiO}_{2}$ & $\mathrm{TiO}_{2}$ & $\mathrm{Al}_{2} \mathrm{O}_{3}$ & $\mathrm{Fe}_{2} \mathrm{O}_{3}$ & $\mathrm{MnO}$ & $\mathrm{MgO}$ & $\mathrm{CaO}$ & $\mathrm{Na}_{2} \mathrm{O}$ & $\mathrm{K}_{2} \mathrm{O}$ & $\mathrm{P}_{2} \mathrm{O}_{5}$ & Total & LOI \\
\hline \multicolumn{15}{|l|}{$\begin{array}{l}\text { Limalok Guyot: } \\
144-871 \mathrm{C}-\end{array}$} \\
\hline $33 \mathrm{R}-3,116-120$ & Clast & & 43.51 & 2.72 & 12.46 & 11.55 & 0.20 & 13.73 & 10.84 & 3.54 & 0.99 & 0.34 & 99.88 & 1.94 \\
\hline $34 \mathrm{R}-1,5-9$ & Clast & & 42.59 & 3.00 & 11.96 & 11.88 & 0.22 & 10.61 & 16.45 & 1.93 & 0.44 & 0.42 & 99.49 & 4.44 \\
\hline $35 \mathrm{R}-1,44-50$ & 1 & & 43.26 & 3.98 & 11.77 & 11.17 & 0.52 & 13.36 & 12.92 & 1.73 & 0.42 & 0.42 & 99.55 & 6.50 \\
\hline $35 \mathrm{R}-4,42-48$ & 6 & & 42.24 & 4.24 & 14.39 & 15.53 & 0.29 & 14.44 & 6.35 & 1.29 & 0.62 & 0.56 & 99.94 & 8.78 \\
\hline $36 \mathrm{R}-3,25-31$ & 13 & & 42.80 & 3.01 & 12.32 & 13.31 & 0.26 & 14.87 & 12.13 & 0.86 & 0.18 & 0.53 & 100.27 & 6.05 \\
\hline $37 \mathrm{R}-1,80-84$ & 15 & & 41.53 & 3.45 & 13.93 & 15.62 & 0.25 & 17.84 & 6.29 & 0.98 & 0.79 & 0.47 & 101.13 & 8.12 \\
\hline $38 \mathrm{R}-1,86-91$ & 17 & & 43.05 & 2.95 & 12.00 & 13.01 & 0.22 & 15.56 & 11.06 & 1.53 & 0.49 & 0.47 & 100.33 & 5.02 \\
\hline $38 \mathrm{R}-6,98-100$ & 19 & & 41.63 & 3.29 & 12.47 & 13.88 & 0.21 & 13.71 & 12.63 & 0.88 & 0.36 & 0.59 & 99.64 & 3.97 \\
\hline $39 \mathrm{R}-1,53-55$ & $21 \mathrm{a}$ & & 41.77 & 3.35 & 11.94 & 14.24 & 0.23 & 14.81 & 12.37 & 0.81 & 0.29 & 0.55 & 100.36 & 5.02 \\
\hline $39 \mathrm{R}-3,62-65$ & $21 \mathrm{~d}$ & & 42.49 & 3.27 & 11.83 & 13.94 & 0.20 & 13.16 & 12.71 & 1.46 & 0.70 & 0.52 & 100.29 & 3.43 \\
\hline $39 \mathrm{R}-4,57-61$ & 2If & & 41.49 & 3.72 & 11.43 & 16.67 & 0.21 & 19.55 & 6.01 & 1.12 & 0.31 & 0.46 & 100.95 & 6.34 \\
\hline $39 R-5,103-106$ & $21 \mathrm{~g}$ & & 42.69 & 3.27 & 10.89 & 14.62 & 0.20 & 15.92 & 10.91 & 1.07 & 0.50 & 0.44 & 100.51 & 4.66 \\
\hline $40 \mathrm{R}-1,46-50$ & $22 \mathrm{a}$ & & 42.10 & 3.13 & 10.59 & 14.37 & 0.20 & 17.55 & 10.60 & 1.08 & 0.53 & 0.42 & 100.58 & 3.62 \\
\hline $40 \mathrm{R}-4,99-103$ & $22 \mathrm{~g}$ & & 41.72 & 3.20 & 10.65 & 13.80 & 0.21 & 17.17 & 12.48 & 0.51 & 0.12 & 0.49 & 100.35 & 5.92 \\
\hline $41 \mathrm{~B}-1,11-13$ & 23 & & 41.07 & 3.17 & 10.89 & 14.59 & 0.22 & 18.93 & 10.54 & 0.29 & 0.12 & 0.52 & 100.34 & 7.13 \\
\hline \multicolumn{15}{|l|}{$\begin{array}{l}\text { Lo-En Guyot: } \\
144-872 \mathrm{~B}-\end{array}$} \\
\hline $5 \mathrm{R}-1,45-47$ & 6 & & 49.05 & 2.59 & 16.25 & 11.05 & 0.13 & 6.10 & 10.23 & 2.90 & 1.40 & 0.30 & 100.0 & 11.75 \\
\hline $5 R-3,104-108$ & $9 \mathrm{~b}$ & & 49.12 & 2.15 & 15.64 & 10.85 & 0.15 & 8.51 & 9.04 & 2.71 & 1.20 & 0.23 & 99.58 & 3.98 \\
\hline $6 \mathrm{R}-1,75-80$ & 11 & & 49.46 & 2.34 & 16.03 & 10.50 & 0.13 & 6.98 & 10.51 & 2.83 & 0.94 & 0.25 & 99.95 & 2.18 \\
\hline $7 R-4,65-67$ & $14 \mathrm{~b}$ & & 49.24 & 2.41 & 16.71 & 11.16 & 0.16 & 8.05 & 7.85 & 2.85 & 1.35 & 0.27 & 100.03 & 4.05 \\
\hline $8 \mathrm{R}-2,89-92$ & $16 \mathrm{~b}$ & & 48.81 & 2.46 & 15.95 & 10.70 & 0.16 & 6.27 & 10.41 & 3.18 & 1.12 & 0.29 & 99.35 & 2.49 \\
\hline $9 \mathrm{R}-5,131-133$ & $18 \mathrm{~b}$ & & 52.77 & 1.96 & 13.99 & 10.20 & 0.09 & 10.07 & 7.56 & 2.88 & 0.56 & 0.11 & 100.18 & 4.63 \\
\hline $144-872 \mathrm{C}$ - & & & & & & & & & & & & & & \\
\hline $18 \mathrm{X}-2,26-28$ & 1 & & 49,40 & 2.47 & 17.08 & 11.27 & 0.15 & 7.80 & 7.07 & 3.04 & 1.42 & 0.27 & 99.95 & 4.19 \\
\hline \multicolumn{15}{|l|}{ Wodejebato Guyot: } \\
\hline $\begin{array}{l}144-874 \mathrm{~B}- \\
24 \mathrm{R}-4,26-32\end{array}$ & & & 46.41 & 1.74 & 13.16 & 11.65 & 0.17 & 13.48 & 10.71 & 1.93 & 0.76 & 0.23 & 100.23 & 2.11 \\
\hline \multicolumn{15}{|l|}{$\begin{array}{l}\text { MIT Guyot: } \\
144-878 \AA \text { - }\end{array}$} \\
\hline $46 \mathrm{M}-1,112-114$ & Breccia & & 48.28 & 3.12 & 16.09 & 10.02 & 0.10 & 6.70 & 9.91 & 2.81 & 1.45 & 0.51 & 98.99 & 2.87 \\
\hline $78 R-1.127-129$ & 1 & 1 & 49.20 & 3.43 & 17.58 & 10.80 & 0.19 & 4.33 & 7.28 & 3.41 & 1.88 & 0.70 & 98.80 & 2.30 \\
\hline $78 \mathrm{R}-2,71-73$ & i & i & 48.14 & 3.36 & 17.24 & 12.03 & 0.12 & 3.41 & 8.34 & 3.32 & 2.14 & 0.64 & 98.73 & 2.40 \\
\hline $80 \mathrm{R}-6,98-101$ & 8 & 2 & 42.93 & 3.71 & 12.20 & 13.16 & 0.18 & 12.91 & 12.06 & 1.50 & 0.60 & 0.52 & 99.79 & 3.29 \\
\hline $81 R-2,114-118$ & 10 & 2 & 43.21 & 3.81 & 12.36 & 13.15 & 0.29 & 12.65 & 12.13 & 0.97 & 0.56 & 0.60 & 99.73 & 3.97 \\
\hline $81 \mathrm{R}-5,22-25$ & 11 & 2 & 45.40 & 3.97 & 14.60 & 13.00 & 0.42 & 7.77 & 10.14 & 1.74 & 1.51 & 0.63 & 99.17 & 3.21 \\
\hline $85 \mathrm{R}-2,90-92$ & 16 & 2 & 44.00 & 3.46 & 13.79 & 13.34 & 0.34 & 10.66 & 11.11 & 1.15 & 1.13 & 0.55 & 99.51 & 4.20 \\
\hline $88 \mathrm{R}-3,4-6$ & 20 & 3 & 47.44 & 3.63 & 14.93 & 13.14 & 0.50 & 5.43 & 7.92 & 2.89 & 1.75 & 0.56 & 98.18 & 2.88 \\
\hline $89 R-4,45-47$ & 21 & 3 & 47.71 & 3.19 & 14.32 & 12.22 & 0.19 & 7.50 & 8.37 & 2.89 & 1.55 & 0.55 & 98.48 & 2.46 \\
\hline $90 R-1,105-107$ & 21 & 3 & 49.11 & 3.02 & 14.88 & 12.03 & 0.18 & 5.18 & 8.44 & 3.20 & 1.78 & 0.61 & 98.43 & 2.61 \\
\hline $91 \mathrm{R}-3,94-97$ & 23 & 4 & 48.27 & 3.44 & 15.05 & 12.04 & 0.16 & 6.46 & 8.11 & 2.92 & 1.59 & 0.63 & 98.65 & 1.96 \\
\hline $92 \mathrm{R}-1,101-103$ & 24 & 4 & 49.36 & 3.52 & 15.06 & 11.56 & 0.45 & 7.21 & 7.70 & 2.77 & 1.46 & 0.52 & 99.60 & 3,39 \\
\hline $92 \mathrm{R}-4,78-81$ & 26 & 5 & 48.86 & 3.53 & 14.95 & 11.68 & 0.25 & 6.74 & 8.77 & 2.92 & 1.38 & 0.52 & 99.59 & 2.80 \\
\hline $92 \mathrm{R}-5,41-45$ & 27 & 5 & 48.93 & 3.51 & 14.85 & 11.19 & 0.19 & 6.59 & 9.11 & 2.81 & 1.36 & 0.50 & 99.02 & 2.51 \\
\hline $93 R-2,123-125$ & 30 & 5 & 48.00 & 3.38 & 15.09 & 12.61 & 0.44 & 4.92 & 8.52 & 3.10 & 1.45 & 0.55 & 98.06 & 2.81 \\
\hline $95 R-6,2-5$ & 32 & 6 & 49.38 & 3.62 & 15.82 & 11.62 & 0.21 & 5.17 & 8.75 & 3.04 & 1.33 & 0.53 & 99.46 & 2.00 \\
\hline $97 \mathrm{R}-1,28-31$ & 34 & 6 & 48.23 & 3.45 & 14.91 & 12.72 & 0.17 & 6.45 & 8.61 & 2.87 & 1.26 & 0.50 & 99.17 & 0.58 \\
\hline $97 \mathrm{R}-2,128-130$ & 34 & 6 & 48.03 & 3.46 & 14.90 & 12.76 & 0.19 & 6.41 & 8.62 & 2.93 & 1.28 & 0.51 & 99.08 & 0.79 \\
\hline $98 \mathrm{R}-3,46-48$ & 35 & 7 & 47.13 & 3.39 & 14.01 & 12.63 & 0.16 & 8.73 & 9.34 & 2.31 & 1.26 & 0.44 & 99.39 & 1.59 \\
\hline
\end{tabular}

Notes: All analyses by shipboard XRF except for Sample 144-874B-24R-4, 26-32 cm, which was analyzed at the University of Massachusetts at Amherst (see text). The igneous units are as defined by lithology aboard ship. Petrographic types are for Site 878 only (see text). LOI $=$ loss on ignition.

and MIT form a cluster spanning a wide range of high-MgO values, but no systematic variations in other elements are apparent. The remaining MIT lavas form a second cluster at higher trace element concentrations and lower $\mathrm{MgO}$. Again, there is no apparent systematic variation within the group. Only the Lo-En lavas appear to define a distinct trend of increasing trace element content with decreasing $\mathrm{MgO}$, which perhaps reflects processes of crystal fractionation.

\section{Element Abundance Patterns}

"Spider diagrams" provide a convenient way of characterizing mantle trace element populations in terms of larger groups of elements than simple ratio diagrams. In addition, they provide a useful means of checking whether certain mobile trace elements have been removed from, or added to, samples by alteration processes. In Figure 4, we show spider diagrams for each of the guyots based on trace element values normalized to the primitive mantle values of Sun and McDonough (1989). A field for recently analyzed Tahiti lavas (Duncan et al., 1994) is included in each diagram for comparison. Two points emerge very clearly from these diagrams.

Potassium, rubidium and, to a lesser extent, barium and strontium concentrations have been strongly affected by alteration. The patterns for the Limalok (Site 871) basanites are quite irregular, and all the samples have lost $\mathrm{K}$ and $\mathrm{Rb}$, presumably as groundmass nepheline and/or feldspar is converted to clay minerals. In some cases, the losses have been extreme. Site 871 lavas have also lost smaller and variable amounts of barium, strontium, and, surprisingly, phosphorus. The basanites from MIT Guyot (Site 878) have also lost K and Rb. The patterns from Wodejebato lavas, although based on fewer elements, are also quite variable, perhaps reflecting more pervasive alteration, but actual losses of mobile elements from the samples have been much smaller.

Relative abundances of the remaining, more immobile, elements are remarkably similar for all Leg 144 lavas. The abundance patterns are all quite similar to one another and to the Tahiti pattern, implying that mantle compositions and extent of melting were relatively uniform throughout the region in which the guyots formed and that similar conditions persist in the SOPITA region today.

Within each guyot, rare earth element (REE) abundance patterns (Fig. 5) are also quite uniform and consistently light rare earth element (LREE) enriched. Patterns vary somewhat among the guyots, reflecting variability in source composition and/or extent of melting. Limalok, Lo-En, and MIT lavas all have comparably steep patterns and similar abundances. Wodejebato lavas have flatter patterns and are more variable, especially in $\mathrm{La}$ and $\mathrm{Ce}$, reflecting either the greater 
Table 2. Trace element analyses of Leg 144 samples by XRF.

\begin{tabular}{|c|c|c|c|c|c|c|c|c|c|c|c|c|}
\hline $\begin{array}{l}\text { Core, section, } \\
\text { interval }(\mathrm{cm})\end{array}$ & $\begin{array}{l}\text { Igneous } \\
\text { unit }\end{array}$ & $\begin{array}{c}\text { Petrographic } \\
\text { type }\end{array}$ & $\mathrm{Ba}$ & $\mathrm{Rb}$ & K & $\mathrm{Nb}$ & $\mathrm{Ce}$ & $\mathrm{Sr}$ & $\mathbf{P}$ & $\mathrm{Zr}$ & $\mathrm{Ti}$ & $\mathrm{Y}$ \\
\hline \multicolumn{13}{|l|}{ Limalok Guyot: } \\
\hline $33 \mathrm{R}-3,116-120$ & Clast & & 669 & 23 & 8218 & 97 & 75 & 695 & 1484 & 299 & 16306 & 25 \\
\hline $34 \mathrm{R}-1,5-9$ & Clast & & 570 & 8 & 3653 & 68 & 88 & 772 & 1833 & 215 & 17985 & 27 \\
\hline $35 \mathrm{R}-1,44-50$ & 1 & & 701 & 11 & 3487 & 65 & 86 & 644 & 1833 & 241 & 23860 & 23 \\
\hline $35 \mathrm{R}-4,42-48$ & 6 & & 362 & 20 & 5147 & 85 & 95 & 279 & 2444 & 275 & 25418 & 33 \\
\hline $36 \mathrm{R}-3,25-31$ & 13 & & 357 & 7 & 1494 & 73 & 90 & 508 & 2313 & 230 & 18045 & 27 \\
\hline $37 \mathrm{R}-1,80-84$ & 15 & & 443 & 12 & 6558 & 82 & 97 & 304 & 2051 & 252 & 20682 & 29 \\
\hline $38 \mathrm{R}-1,86-91$ & 17 & & 400 & 10 & 4068 & 73 & 76 & 511 & 2051 & 227 & 17685 & 27 \\
\hline $38 R-6,98-100$ & 19 & & 499 & 10 & 2989 & 72 & 95 & 568 & 2575 & 207 & 19723 & 31 \\
\hline $39 \mathrm{R}-1,53-55$ & $21 \mathrm{a}$ & & 394 & 10 & 2407 & 65 & 94 & 355 & 2400 & 200 & 20083 & 28 \\
\hline $39 R-3,62-65$ & 21d & & 431 & 21 & 5811 & 66 & 90 & 534 & 2269 & 197 & 19603 & 28 \\
\hline $39 \mathrm{R}-4,57-61$ & $21 \mathrm{f}$ & & 105 & 9 & 2573 & 55 & 67 & 163 & 2007 & 202 & 22301 & 24 \\
\hline $39 R-5,103-106$ & $21 \mathrm{~g}$ & & 361 & 16 & 4151 & 53 & 61 & 456 & 1920 & 187 & 19603 & 24 \\
\hline $40 \mathrm{R}-1,46-50$ & $22 \mathrm{a}$ & & 446 & 18 & 4400 & 53 & 70 & 524 & 1833 & 186 & 18764 & 24 \\
\hline $40 R-4,99-103$ & $22 \mathrm{~g}$ & & 354 & 12 & 996 & 62 & 77 & 335 & 2138 & 206 & 19184 & 26 \\
\hline $41 \mathrm{~B}-1,11-13$ & 23 & & 347 & 8 & 996 & 65 & 84 & 295 & 2269 & 205 & 19004 & 27 \\
\hline \multicolumn{13}{|l|}{$\begin{array}{l}\text { Lo-En Guyot: } \\
\text { 144-872B- }\end{array}$} \\
\hline $5 \mathrm{R}-1,45-47$ & 6 & & 305 & 27 & 11622 & 46 & 59 & 530 & 1309 & 194 & 15527 & 23 \\
\hline $5 R-3,104-108$ & $9 \mathrm{~b}$ & & 222 & 26 & 9962 & 33 & 43 & 375 & 1004 & 159 & 12889 & 20 \\
\hline $6 \mathrm{R}-1,75-80$ & 11 & & 244 & 22 & 7803 & 35 & 47 & 426 & 1091 & 168 & 14028 & 22 \\
\hline $7 R-4,65-67$ & $14 \mathrm{~b}$ & & 226 & 24 & 11207 & 39 & 53 & 351 & 1178 & 175 & 14448 & 21 \\
\hline $8 \mathrm{R}-2,89-92$ & $16 \mathrm{~b}$ & & 231 & 24 & 9298 & 42 & 62 & 429 & 1266 & 199 & 14747 & 23 \\
\hline $9 \mathrm{R}-5,131-133$ & $18 \mathrm{~b}$ & & 83 & 3 & 4649 & 20 & 28 & 255 & 480 & 114 & 11750 & 16 \\
\hline \multicolumn{13}{|l|}{ 144-872C- } \\
\hline $18 X-2,26-28$ & 1 & & 252 & 25 & 11788 & 37 & 49 & 426 & 1178 & 275 & 14807 & 25 \\
\hline \multicolumn{13}{|l|}{$\begin{array}{l}\text { Wodejebato Guyot: } \\
\text { 144-874B- } \\
24 \mathrm{R}-4,26-32\end{array}$} \\
\hline \multicolumn{13}{|l|}{$\begin{array}{l}\text { MIT Guyot: } \\
144-878 \mathrm{~A}-\end{array}$} \\
\hline $46 \mathrm{M}-1,112-114$ & Breccia & & 403 & 27 & 12037 & 52 & 76 & 590 & 2226 & 306 & 18704 & 31 \\
\hline $78 \mathrm{R}-1,127-129$ & 1 & 1 & 544 & 34 & 15607 & 70 & 96 & 728 & 3055 & 297 & 20562 & 31 \\
\hline $78 \mathrm{R}-2,71-73$ & 1 & 1 & 538 & 38 & 17765 & 69 & 93 & 817 & 2793 & 313 & 20143 & 27 \\
\hline $80 \mathrm{R}-6,98-101$ & 8 & 2 & 387 & 10 & 4981 & 65 & 93 & 632 & 2269 & 315 & 22241 & 28 \\
\hline $81 R-2,114-118$ & 10 & 2 & 358 & 9 & 4649 & 64 & 93 & 570 & 2618 & 347 & 22841 & 32 \\
\hline $81 \mathrm{R}-5,22-25$ & 11 & 2 & 449 & 31 & 12535 & 65 & 95 & 691 & 2749 & 328 & 23800 & 30 \\
\hline $85 \mathrm{R}-2,90-92$ & 16 & 2 & 405 & 26 & 9381 & 72 & 97 & 649 & 2400 & 291 & 20742 & 33 \\
\hline $88 \mathrm{R}-3,4-6$ & 20 & 3 & 452 & 30 & 14528 & 60 & 90 & 640 & 2444 & 324 & 21761 & 33 \\
\hline $89 R-4,45-47$ & 21 & 3 & 462 & 39 & 12867 & 59 & 82 & 644 & 2400 & 360 & 19124 & 36 \\
\hline $90 \mathrm{R}-1,105-107$ & 21 & 3 & 447 & 42 & 14777 & 64 & 92 & 631 & 2662 & 395 & 18105 & 39 \\
\hline $91 \mathrm{R}-3,94-97$ & 23 & 4 & 394 & 36 & 13199 & 54 & 89 & 645 & 2749 & 317 & 20622 & 35 \\
\hline $92 \mathrm{R}-1,101-103$ & 24 & 4 & 348 & 32 & 12120 & 50 & 73 & 491 & 2269 & 317 & 21102 & 34 \\
\hline $92 \mathrm{R}-4,78-81$ & 26 & 5 & 372 & 33 & 11456 & 48 & 68 & 553 & 2269 & 311 & 21162 & 33 \\
\hline $92 \mathrm{R}-5,41-45$ & 27 & 5 & 380 & 32 & 11290 & 48 & 67 & 566 & 2182 & 328 & 21042 & 37 \\
\hline $93 \mathrm{R}-2,123-125$ & 30 & 5 & 388 & 34 & 12037 & 52 & 79 & 580 & 2400 & 322 & 20263 & 38 \\
\hline $95 R-6,2-5$ & 32 & 6 & 359 & 30 & 11041 & 49 & 68 & 618 & 2313 & 317 & 21702 & 38 \\
\hline $97 \mathrm{R}-1,28-31$ & 34 & 6 & 373 & 28 & 10460 & 48 & 69 & 617 & 2182 & 318 & 20682 & 37 \\
\hline $97 \mathrm{R}-2,128-130$ & 34 & 6 & 388 & 29 & 10626 & 48 & 67 & 616 & 2226 & 296 & 20742 & 31 \\
\hline $98 \mathrm{R}-3,46-48$ & 35 & 7 & 388 & 31 & 10460 & 51 & 77 & 611 & 1920 & 296 & 20323 & 31 \\
\hline
\end{tabular}

Notes: All analyses by shipboard XRF except for Sample 144-874B-24R-4, 26-32 cm, which was analyzed at the University of Massachusetts at Amherst (see text). Igneous units are as defined by lithology aboard ship. Petrographic types for Site 878 are as defined in text.

spatial coverage of the several sites or the more pervasive alteration. The flattest pattern is for the Takuyo-Daisan lava which appears to be transitional or tholeiitic in character. Because this lava is strongly plagioclase phyric, this analysis is for a groundmass separate and measured concentrations may not reflect actual magmatic liquid values.

\section{Incompatible Element Ratios}

Slightly more insight into the origins of some of the observed geochemical variations can be obtained from a plot of $\mathrm{La} / \mathrm{Yb}$ vs. La (Fig. $5 \mathrm{~A})$. In such a plot, the effects of crystal fractionation appear as nearly horizontal trends, reflecting increases in REE abundance as crystals are separated from liquid. Changes in extent of partial melting can affect the ratio and create steep trends. Differences between such trends may reflect variations in mantle ratios. With the possible exception of Site 873 , lavas from each site define nearly vertical trends or tight clusters on this diagram, suggesting that lavas from each site were derived from mantle of slightly different composition, and that within-site variations reflect primarily changes in the extent of melting. Note that the basanites of Limalok and MIT have the highest La/Yb ratios, which suggests that they represent the lowest extent of melting. The Site 873 (Wodejebato) lavas form a more nearly horizontal trend, encompass- ing the highest measured La concentrations, and suggesting that crystal fractionation has played a role at this site. Taken together, however, lavas from all the Wodejebato sites are dispersed across the diagram, suggesting that the range of source ratios for this guyot is as great as that for the entire sample suite.

A variety of incompatible element ratios and ratio pairs can be used to characterize the mantle sources from which the lava suites are derived. For modern SOPITA lavas, one useful example is a plot of $\mathrm{Ba} / \mathrm{Zr}$ vs. $\mathrm{Nb} / \mathrm{Zr}$ ( $\mathrm{Zr}$ is used in the denominator to compensate for increases in $\mathrm{Ba}$ and $\mathrm{Nb}$ resulting solely from crystal fractionation), which illustrates the diversity of modern mantle source compositions (Fig. 6). For most of the Leg 144 lavas, the range of $\mathrm{Ba} / \mathrm{Nb}$ is a rather limited (2-8) subset of the much larger range (2-12) encompassed by published data from the present-day SOPITA islands. Important exceptions are a number of the Limalok basanites that have highly variable $\mathrm{Ba} / \mathrm{Nb}$ (and $\mathrm{Ba} / \mathrm{Zr}$ ) ratios (2-10), but relatively constant $\mathrm{Nb} / \mathrm{Zr}$. Given the altered state of these lavas and the observed scatter in normalized $\mathrm{Ba}$ abundances, we suggest that most or all of this scatter reflects addition of $\mathrm{Ba}$ from seawater and/or redistribution of $\mathrm{Ba}$ within some lavas as a result of low temperature alteration processes. The distribution of data in Figure 6, and the overall consistency of trace element abundance patterns in the leg 144 lavas (see below) further suggest that 
Table 3. Trace element analyses of Leg 144 samples by ICP-MS.

\begin{tabular}{|c|c|c|c|c|c|c|c|c|c|c|}
\hline $\begin{array}{l}\text { Laboratory: } \\
\text { Hole: } \\
\text { Core, section: } \\
\text { Interval }(\mathrm{cm}) \text { : }\end{array}$ & $\begin{array}{l}\text { SIO } \\
871 \mathrm{C} \\
35 \mathrm{R}-1 \\
44-50\end{array}$ & $\begin{array}{c}\text { SIO } \\
871 \mathrm{C} \\
38 \mathrm{R}-1 \\
86-91\end{array}$ & $\begin{array}{l}\text { SIO } \\
871 \mathrm{C} \\
40 \mathrm{R}-1 \\
46-50\end{array}$ & $\begin{array}{l}\text { SIO } \\
872 B \\
5 R-1 \\
45-47\end{array}$ & $\begin{array}{c}\text { SIO } \\
872 \mathrm{~B} \\
5 \mathrm{R}-3 \\
104-108\end{array}$ & $\begin{array}{c}\text { SIO } \\
872 B \\
6 \mathrm{R}-1 \\
75-80\end{array}$ & $\begin{array}{l}\text { SIO } \\
872 B \\
7 R-4 \\
65-67\end{array}$ & $\begin{array}{l}\text { OSU } \\
873 \mathrm{~A} \\
17 \mathrm{R}-1 \\
12-15\end{array}$ & $\begin{array}{l}\text { OSU } \\
873 \mathrm{~A} \\
18 \mathrm{R}-1 \\
19-22\end{array}$ & $\begin{array}{l}\text { OSU } \\
873 \mathrm{~A} \\
\text { 19R-3 } \\
94-98\end{array}$ \\
\hline $\mathrm{Rb}$ & & & & & & & & 38 & 56 & 67 \\
\hline $\mathrm{Sr}$ & & & & & & & & 720 & 796 & 259 \\
\hline $\mathrm{Y}$ & & & & & & & & 42 & 46 & 27 \\
\hline $\mathrm{Zr}$ & & & & & & & & 244 & 339 & 188 \\
\hline $\mathrm{Nb}$ & & & & & & & & 61 & 79 & 41 \\
\hline Cs & & & & & & & & 0.31 & 0.33 & 0.62 \\
\hline $\mathrm{Ba}$ & 785 & 450 & 434 & 302 & 222 & 235 & 237 & 455 & 541 & 336 \\
\hline $\mathrm{La}$ & 107 & 115 & 83 & 79 & 56 & 71 & 73 & 36 & 51 & 25 \\
\hline $\mathrm{Ce}$ & 87 & 86 & 66 & 63 & 48 & 53 & 56 & 91 & 129 & 45 \\
\hline $\mathrm{Pr}$ & & & & & & & & 12.5 & 16.6 & 5.9 \\
\hline $\mathrm{Nd}$ & 58 & 54 & 47 & 41 & 32 & 30 & 31 & 43 & 53 & 24 \\
\hline $\mathrm{Sm}$ & 33 & 33 & 30 & 25 & 20 & 21 & 19 & 9.1 & 10.5 & 4.8 \\
\hline Eu & 28 & 27 & 25 & 22 & 19 & 23 & 19 & 2.7 & 2.9 & 1.6 \\
\hline Gd & & & & & & & & 9.1 & 10.1 & 4.9 \\
\hline $\mathrm{Tb}$ & & & & & & & & 1.2 & 1.3 & 0.8 \\
\hline Dy & 10.5 & 11.2 & 10.2 & 9.8 & 7.9 & 9.8 & 8.7 & 6.5 & 7.0 & 4.3 \\
\hline Ho & & & & & & & & 1.2 & 1.3 & 0.8 \\
\hline Er & 6.9 & 7.9 & 7.0 & 7.2 & 5.7 & 7.6 & 6.2 & 3.1 & 3.4 & 2.2 \\
\hline $\mathrm{Tm}$ & & & & & & & & 0.4 & 0.5 & 0.3 \\
\hline $\mathrm{Yb}$ & 5.1 & 6.6 & 5.4 & 6.3 & 4.8 & 6.7 & 5.5 & 2.6 & 2.9 & 1.9 \\
\hline $\mathrm{Lu}$ & & & & & & & & 0.36 & 0.42 & 0.27 \\
\hline $\mathrm{Hf}$ & & & & & & & & 5.7 & 7.0 & 4.4 \\
\hline Ta & & & & & & & & 2.9 & 3.7 & 1.9 \\
\hline $\mathrm{Pb}$ & & & & & & & & 4.6 & 7.4 & 2.7 \\
\hline Th & & & & & & & & 4.9 & 7.7 & 3.5 \\
\hline $\mathrm{U}$ & & & & & & & & 1.6 & 1.7 & 1.9 \\
\hline $\mathrm{Sc}$ & & & & & & & & 16 & 8 & 23 \\
\hline V & & & & & & & & 210 & 86 & 449 \\
\hline $\mathrm{Cr}$ & & & & & & & & 8 & 8 & 8 \\
\hline $\mathrm{Co}$ & & & & & & & & 40 & 28 & 39 \\
\hline $\mathrm{Ni}$ & & & & & & & & 22 & 20 & 21 \\
\hline $\mathrm{Cu}$ & & & & & & & & 24 & 14 & 23 \\
\hline $\mathrm{Zn}$ & & & & & & & & 119 & 113 & 117 \\
\hline
\end{tabular}

Notes: Laboratory indicated is where samples were prepared. All analyses were run at OSU (see text). Single asterisk $(*)$ indicates a groundmass separate.

the original $\mathrm{Ba} / \mathrm{Nb}$ ratios for these altered suites are close to the minimum values presently observed.

Several of these observations are in apparent conflict with those discussed earlier in relation to $\mathrm{MgO}$ variations. The MIT lavas (Site 878 ) vary widely in $\mathrm{MgO}$ content, implying that some form of differentiation has occurred, yet the trace element data display no evidence for such a process. Moreover, this apparent trace element uniformity exists despite the observation that these lavas appear to represent at least two, and probably three, eruptive episodes, separated by a significant time breaks (up to $1 \mathrm{Ma}$ ) (Pringle and Duncan, this volume) and by significant subaerial weathering and/or erosion intervals. Lavas of Site 872 appear to define clear fractionation trends on most of the $\mathrm{MgO}$ variation diagrams discussed above, yet there is no evidence of this fractionation in these REE systematics. The reason for these discrepancies is unclear. They may partly reflect remobilization of $\mathrm{MgO}$ and other elements during alteration. They may also partially reflect more complex variations in the mantle source.

\section{MINERAL CHEMISTRY}

Information derived from well preserved mineral grains provides some of the most reliable data about initial magmatic liquid compositions. In this section we present a brief overview of the mineral chemistry of the Leg 144 lavas, as it relates to magma chemistry. A more detailed treatment of the mineral data is given by Dieu (this volume).

\section{Olivine}

Of the Leg 144 lavas, only portions of the ankaramite of Hole 874B (Wodejebato Guyot) and a type 2 basanite (Unit 15) from Hole 878A (MIT Guyot) contain unaltered olivine phenocrysts. An unaltered dunite xenolith was also sampled from igneous Unit 23 of Hole $878 \mathrm{~A}$. Fresh groundmass olivine was not found. Olivine grains from both lavas are relatively primitive, with Fo contents between 81 and 86 , equivalent to liquid magnesium numbers $(\mathrm{Mg} \# ; \mathrm{Mg} /(\mathrm{Mg}+\mathrm{Fe})$ of
$0.62-0.65$ (calculations after Roeder and Emslie, 1970, $K_{D}=0.30$ ). These values are, however, much less than the Mg\# values (79-85) calculated from whole-rock analyses of Unit 2 lavas (Table 1), again suggesting that the high $\mathrm{MgO}$ values of the basanites result, in part, from the addition of xenocrystal olivine.

\section{Clinopyroxene}

Unaltered clinopyroxene is almost ubiquitous in Leg 144 lavas, enabling a representative sample of groundmass, phenocrysts, and xenocrysts to be analyzed. These data are displayed in Figures 7 and 8 and are consistent with the earlier petrographic determinations of lava type.

Leg 144 clinopyroxenes display a broad trend of increasing $\mathrm{TiO}_{2}$ with decreasing Mg\# (Fig. 7), the most mafic being those from the Wodejebato ankaramites which have $\mathrm{Mg \#}>0.85$, consistent with their crystallization from very mafic liquids. Relative to clinopyroxene phenocrysts from Hawaiian lavas, Leg 144 clinopyroxene compositions plot either within the alkalic field or at higher $\mathrm{TiO}_{2}$ contents, although there is considerable overlap between the Hawaiian tholeiitic and alkalic fields. Most of the high $\mathrm{TiO}_{2}$ clinopyroxenes are from the basanites of Limalok and MIT guyots, which have higher $\mathrm{TiO}_{2}$ contents than most Hawaiian lavas. Generally high $\mathrm{TiO}_{2}$ contents of Leg 144 clinopyroxenes may also partly reflect an overall enrichment of their source region relative to Hawaii.

Le Bas (1962) established compositional fields for groundmass clinopyroxenes from nonalkaline (tholeiitic), alkaline, and peralkaline lavas on a ternary diagram of $\mathrm{Fe}+\mathrm{Mn}, \mathrm{Mg}$, and $\mathrm{Ca}+\mathrm{Na}$. With little overlap, this diagram separates groundmass clinopyroxene compositions from Hawaiian tholeiitic, alkalic, and nephelinitic series lavas (Dieu, this volume). This separation potentially provides a very useful tool for evaluating hot spot lavas, but the Le Bas fields do not always agree well with the classification of Leg 144 lavas described above. Clinopyroxenes from the Leg 144 basanites (Limalok and MIT) define a field which is distinct from that of Leg 144 alkalic series lavas, but 
Table 3 (continued).

\begin{tabular}{|c|c|c|c|c|c|c|c|c|c|c|c|}
\hline $\begin{array}{l}\text { Laboratory: } \\
\text { Hole: } \\
\text { Core, section: } \\
\text { Interval (cm): }\end{array}$ & $\begin{array}{l}\text { OSU } \\
876 \mathrm{~A} \\
17 \mathrm{R}-1 \\
51-54\end{array}$ & $\begin{array}{l}\text { OSU } \\
876 \mathrm{~A} \\
17 \mathrm{R}-1 \\
84-90\end{array}$ & $\begin{array}{l}\text { OSU } \\
877 \mathrm{~A} \\
20 \mathrm{R}-5 \\
1-5\end{array}$ & $\begin{array}{c}\text { SIO } \\
878 \mathrm{~A} \\
78 \mathrm{R}-2 \\
71-73\end{array}$ & $\begin{array}{c}\text { SIO } \\
878 \mathrm{~A} \\
81 \mathrm{R}-2 \\
114-118\end{array}$ & $\begin{array}{c}\text { SIO } \\
878 \mathrm{~A} \\
81 \mathrm{R}-5 \\
22-25\end{array}$ & $\begin{array}{c}\text { SIO } \\
878 \mathrm{~A} \\
90 \mathrm{R}-1 \\
105-107\end{array}$ & $\begin{array}{l}\text { SIO } \\
878 \mathrm{~A} \\
91 \mathrm{R}-3 \\
94-97\end{array}$ & $\begin{array}{c}\text { SIO } \\
878 \mathrm{~A} \\
92 \mathrm{R}-5 \\
41-43\end{array}$ & $\begin{array}{c}\text { SIO } \\
878 \mathrm{~A} \\
93 \mathrm{R}-2 \\
123-125\end{array}$ & $\begin{array}{r}\text { OSU } \\
879 \mathrm{~A} \\
22 \mathrm{R}-3^{*} \\
99-104\end{array}$ \\
\hline $\mathrm{Rb}$ & 52 & 36 & 28 & & & & & & & & 29 \\
\hline $\mathrm{Sr}$ & 399 & 451 & 251 & & & & & & & & 520 \\
\hline $\mathrm{Y}$ & 28 & 31 & 25 & & & & & & & & 36 \\
\hline $\mathrm{Zr}$ & 174 & 185 & 164 & & & & & & & & 206 \\
\hline $\mathrm{Nb}$ & 43 & 42 & 27 & & & & & & & & 25 \\
\hline Cs & 1.29 & 0.38 & 0.70 & & & & & & & & 0.56 \\
\hline $\mathrm{Ba}$ & 279 & 301 & 214 & 566 & 360 & 442 & 492 & 415 & 381 & 402 & 223 \\
\hline $\mathrm{La}$ & 31 & 32 & 17 & 122 & 117 & 121 & 119 & 107 & 103 & 99 & 23 \\
\hline $\mathrm{Ce}$ & 60 & 62 & 30 & 96 & 96 & 96 & 92 & 88 & 74 & 79 & 47 \\
\hline Pr & 8.2 & 8.6 & 4.9 & & & 70 & & & & & 7.1 \\
\hline $\mathrm{Nd}$ & 30 & 32 & 22 & 60 & 63 & 62 & 59 & 61 & 49 & 52 & 30 \\
\hline $\mathrm{Sm}$ & 6.0 & 6.4 & 4.7 & 36 & 36 & 38 & 38 & 41 & 33 & 36 & 7.5 \\
\hline $\mathrm{Eu}$ & 2.0 & 2.0 & 1.6 & 33 & 31 & 34 & 46 & 37 & 30 & 33 & 2.5 \\
\hline Gd & 5.9 & 6.4 & 4.7 & & & & & & & & 7.6 \\
\hline $\mathrm{Tb}$ & 0.9 & 0.9 & 0.8 & & & & & & & & 1.2 \\
\hline Dy & 4.6 & 5.0 & 4.1 & 14.2 & 12.7 & 14.5 & 15.7 & 16.9 & 14.1 & 15.8 & 6.5 \\
\hline Ho & 0.8 & 0.9 & 0.7 & & & & & & & & 1.3 \\
\hline $\mathrm{Er}$ & 2.2 & 2.4 & 2.0 & 9.6 & 8.2 & 9.3 & 10.2 & 11.1 & 9.7 & 10.4 & 3.2 \\
\hline $\mathrm{Tm}$ & 0.3 & 0.3 & 0.3 & & & & & & & & 0.5 \\
\hline $\mathrm{Yb}$ & 1.8 & 2.0 & 1.6 & 7.7 & 6.1 & 7.0 & 8.0 & 9.0 & 7.5 & 8.3 & 2.7 \\
\hline $\mathrm{Lu}$ & 0.27 & 0.29 & 0.23 & & & & & & & & 0.38 \\
\hline $\mathrm{Hf}$ & 4.2 & 4.6 & 3.5 & & & & & & & & 5.3 \\
\hline $\mathrm{Ta}$ & 1.9 & 2.0 & 1.2 & & & & & & & & 1.5 \\
\hline $\mathrm{Pb}$ & 3.6 & 3.7 & 2.5 & & & & & & & & 3.0 \\
\hline Th & 3.5 & 3.8 & 2.1 & & & & & & & & 1.7 \\
\hline $\mathrm{U}$ & 1.4 & 1.3 & 2.0 & & & & & & & & 1.2 \\
\hline $\mathrm{Sc}$ & 35 & 32 & 33 & & & & & & & & 30 \\
\hline V & 333 & 304 & 293 & & & & & & & & 276 \\
\hline $\mathrm{Cr}$ & 188 & 157 & 206 & & & & & & & & 102 \\
\hline Co & 46 & 44 & 47 & & & & & & & & 37 \\
\hline $\mathrm{Ni}$ & 67 & 56 & 70 & & & & & & & & 41 \\
\hline $\mathrm{Cu}$ & 44 & 54 & 42 & & & & & & & & 83 \\
\hline $\mathrm{Zn}$ & 111 & 111 & 105 & & & & & & & & 117 \\
\hline
\end{tabular}

which straddles the Le Bas alkaline/peralkaline boundary (Fig. 9). This may suggest that many of our basanites are incorrectly identified, or it may reflect the derivation of these lavas by varying degrees of partial melting within a range that is intermediate between that for alkali basalts and that for extremely alkalic lavas such as nephelinites. Similarly, the field of Lo-En groundmass clinopyroxenes straddles the nonalkaline/alkaline boundary, suggesting that the Lo-En Guyot lavas may be more transitional than alkalic in character. Finally, the single Takuyo-Daisan groundmass clinopyroxene analysis plots well within the nonalkaline field, consistent with its inferred transitional to tholeiitic character.

\section{Feldspar}

In the orthoclase-albite-anorthite ternary diagram (Fig. 9), Leg 144 feldspar phenocrysts, microlites, and poikilitic groundmass grain encompass a wide range of compositions, ranging from $\mathrm{An}_{87.4}$ to $\mathrm{An}_{9.5}$ and reflecting the large range of fractionation represented by the lavas. Fields for phenocrysts from alkalic series lavas of Hiva Oa Island (Marquesas group) and from mid-ocean ridge basalts are shown for comparison. Relative to mid-ocean ridge basalts (MORB), ocean island basalts (OIB) usually crystallize plagioclase with higher Or at equivalent An, reflecting higher abundances of $\mathrm{K}$ in island lavas. Leg 144 plagioclase compositions appear to follow the Hiva Oa phenocryst trend, consistent with the alkalic nature of the Leg 144 lavas. Those feldspars that plot at low An and high Or values, beyond the Hiva Oa field and generally outside the limits of equilibrium feldspar compositions, are microlites and poikilitic groundmass grains that apparently did not crystallize under equilibrium conditions. This scatter is typical of groundmass feldspar compositions in alkalic lavas; and not normally observed for tholeiitic lavas (Keil et al., 1972).

\section{Spinel}

Figure 10 shows $\mathrm{Cr} \#(\mathrm{Cr} /[\mathrm{Cr}+\mathrm{Al}])$ vs. $\mathrm{Mg} \#(\mathrm{Mg} /[\mathrm{Mg}+\mathrm{Fe}])$ for spinel microphenocrysts from Leg 144 lavas, in relation to fields for
Hawaiian alkalic and tholeiitic lavas and for abyssal peridotites. Although these fields are based on relatively few data, there is a clear trend toward higher $\mathrm{Al}$ and lower $\mathrm{Mg}$ with increased alkalinity. Consistent with this trend, spinels from Limalok form a field that overlaps the lower portion of the Hawaiian alkalic field. On the other hand, spinels from the primitive ankaramites of Hole 874B (Wodejebato Guyot) plot outside the Hawaiian alkalic field, and within the Hawaiian tholeiitic field. Given the otherwise very strong alkalic affinities of these lavas, their high Cr\#'s may in some way be a reflection of their primitive compositions. Site 878 (MIT Guyot) spinels are very variable in composition, presumably reflecting the relatively broad range in both alkalinity and degree of differentiation from basanites (low Cr\#'s) to differentiated alkali basalts and hawaiites (moderate Cr\#'s).

\section{CONCLUSIONS}

All of the Leg 144 guyots are built on volcanic substructures which are comparable in size, in geological history and in their petrologic and geochemical character to modern volcanic islands of the SOPITA region. With the exception of the single Takuyo-Daisan lava (which may be transitional or tholeiitic in character), these volcanoes consist of alkalic lavas and volcaniclastics that document histories of eruption, weathering, and erosion in predominantly subaerial and nearshore marine environments. Although their geochemical characteristics are perturbed to varying extents by low-temperature alteration processes, they display a surprising uniformity in those incompatible element ratios and abundance patterns that are not readily affected by alteration. In these characteristics, in the preponderance of mildly to strongly alkalic lavas, and in the considerable local variability displayed by the well-sampled sections, they strongly resemble many modern SOPITA volcanoes, especially those of Tahiti. Perhaps the only real difference is the absence among Leg 144 lavas of the wide geochemical diversity that is a hallmark of the SOPITA region. This absence is most likely a reflection of the small sample size, because available dredge samples display a much greater diversity. 


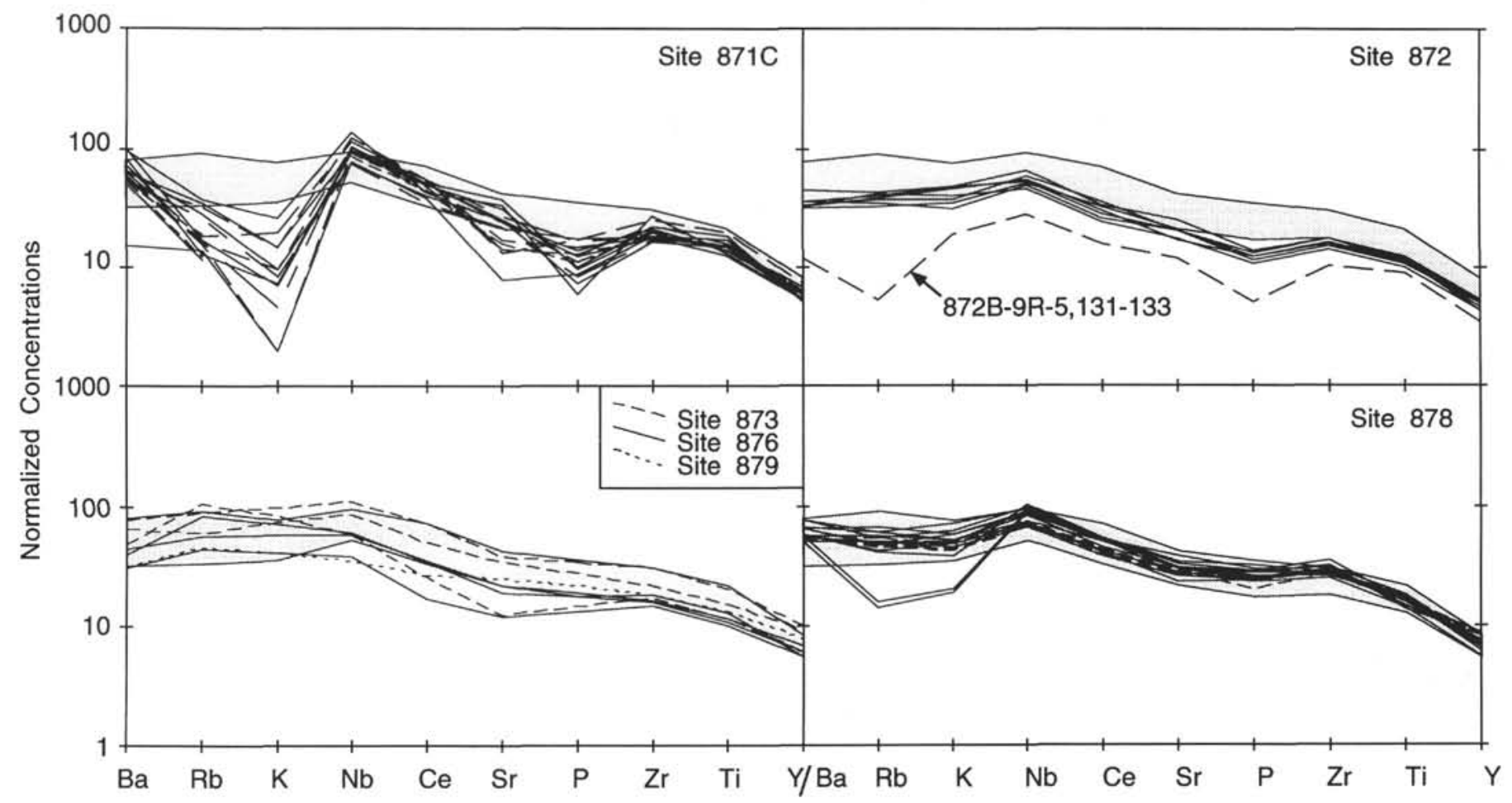

Figure 4. Spider diagrams showing minor and trace element abundances for representative Leg 144 lavas normalized to the primitive mantle composition of Sun and McDonough, 1989. Shaded field is for Tahiti lavas (data of Duncan et al., 1994).
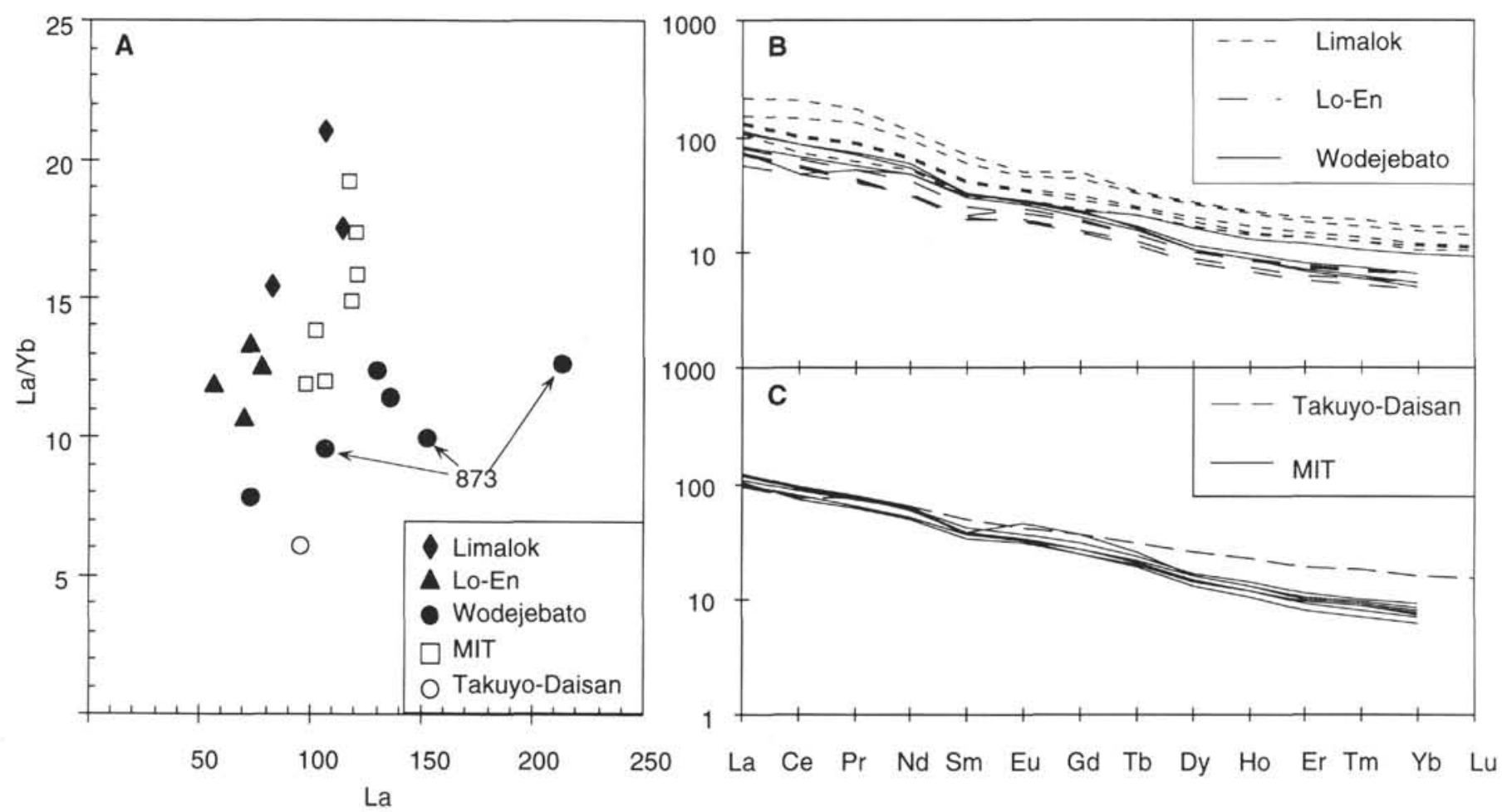

Figure 5. A. La/Yb vs. La concentration (ppm) in Leg 144 lavas. Near-vertical trends for each site except 873 indicate a general absence of crystal fractionation processes. B, C. Chondrite normalized rare earth element abundance patterns for representative Leg 144 lavas. Chondrite values from Sun and McDonough (1989). 


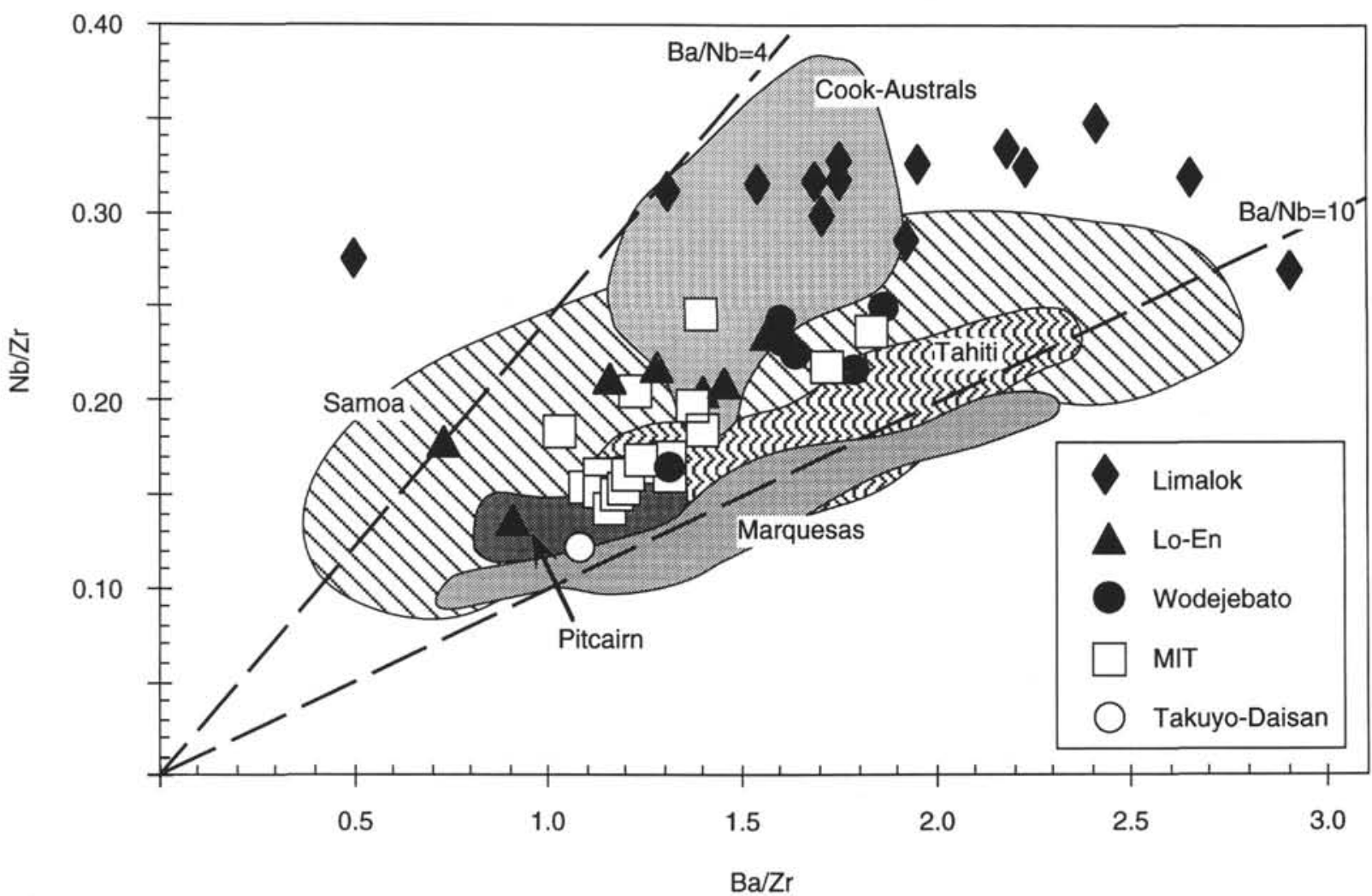

Figure 6. $\mathrm{Nb} / \mathrm{Zr}$ vs. $\mathrm{Ba} / \mathrm{Zr}$ for Leg 144 lavas with fields for a number of SOPITA island chains (data compiled from the literature by J. Dieu). Note that the wide range of $\mathrm{Ba} / \mathrm{Zr}$ values for Limalok lavas most likely reflects remobilization of $\mathrm{Ba}$ during alteration.

\section{REFERENCES}

Chen, C.-Y., Frey, F.A., and Garcia, M.O., 1990. Evolution of alkalic lavas at Haleakala Volcano, East Maui, Hawaii. Contrib. Mineral. Petrol., 105:197-218.

Clague, D.A., Dao-gong, C., Murnane, R., Beeson, M.H., Lanphere, M.A., Dalrymple, G.B., Friesen, W., and Holcomb, R.T., 1982. Age and petrology of the Kalaupapa basalt, Molokai, Hawaii. Pac. Sci., 36:411-420.

Clague, D.A., Fisk, M.R., and Bence, A.E., 1980. Mineral chemistry of basalts from Ojin, Nintoku, and Suiko Seamounts Leg 55 DSDP. In Jackson, E.D., Koizumi, I., et al., Init. Repts. DSDP, 55: Washington (U.S. Govt. Printing Office), 607-637.

Dick, H.J.B., and Bullen, T., 1984. Chromian spinel as a petrogenetic indicator in abyssal and alpine-type peridotites and spatially associated lavas. Contrib. Mineral. Petrol., 86:54-76.

Duncan, R.A., Fisk, M.R., White, W.M., and Neilsen, R.C., 1994. Tahiti: anatomy of a French Polynesian volcano. J. Geophys. Res., 99:2434124357.

Fodor, R.V., Keil, K., and Bunch, T.E., 1975. Contributions to the mineral chemistry of Hawaiian rocks, IV: pyroxenes in rocks from Haleakala and West Maui volcanoes, Maui, Hawaii. Contrib. Mineral. Petrol., 50:173-195.

Frey, F.A., Wise, W.S., Garcia, M.O., West, H., Kwon, S.-T., and Kennedy, A., 1990. Evolution of Mauna Kea Volcano, Hawaii: petrologic and geochemical constraints on postshield volcanism. J. Geophys. Res., 95:1271-1300.

Garcia, M.O., Frey, F.A., and Grooms, D.G., 1986. Petrology of volcanic rocks from Kaula Island, Hawaii. Contrib. Mineral. Petrol., 94:461-471.

Garcia, M.O., Ho, R.A., Rhodes, J.M., and Wolfe, E.W., 1989. Petrologic constraints on rift-zone processes. Bull. Volcanol., 52:81-96.

Gonzales-Marabel, A.-M., 1984. L'ile de Hiva Oa dans les Marquises (Pacifique Central): petrologie et evolution volcanologique [ $\mathrm{Ph} . \mathrm{D}$. thesis]. L'Universite de Paris-Sud, Centre D'Orsay.

\footnotetext{
"Abbreviations for names of organizations and publication titles in ODP reference lists follow the style given in Chemical Abstracts Service Source Index (published by American Chemical Society).
}

Keil, K., Fodor, R.V., and Bunch, T.E., 1972. Contributions to the mineral chemistry of Hawaiian rocks. II: Feldspars and interstitial material in rocks from Haleakala and West Maui volcanoes, Maui, Hawaii. Contrib. Mineral. Petrol., 37:253-276.

Le Bas, M.J., 1962. The role of aluminum in igneous clinopyroxenes with relation to their parentage. Am. J. Sci., 260:267-288.

Lincoln, J.M., Pringle, M.S., and Premoli-Silva, L, 1993. Early and Late Cretaceous volcanism and reef-building in the Marshall Islands. In Pringle, M.S., Sager, W.W., Sliter, W.V., and Stein, S. (Eds.), The Mesozoic Pacific: Geology, Tectonics, and Volcanism. Geophys. Monogr., Am. Geophys. Union, 77:279-305.

Macdonald, G.A., and Katsura, T., 1964. Chemical composition of Hawaiian lavas. J. Petrol, 5:82-133.

McNutt, M.K., and Fischer, K.M., 1987. The South Pacific superswell. In Keating, B.H., Fryer, P., Batiza, R., and Boehlert, G.W. (Eds.), Seamounts, Islands, and Atolls. Geophys. Monogr., Am. Geophys. Union, 43:25-34.

Premoli Silva, I., Haggerty, J., Rack, F., et al., 1993. Proc. ODP, Init. Repts., 144: College Station, TX (Ocean Drilling Program).

Roeder, P.L., and Emslie, R.F., 1970. Olivine-liquid equilibrium. Contrib. Mineral. Petrol., 29:275-289.

Smith, W.H.F., Staudigel, H., Watts, A.B., and Pringle, M.S., 1989. The Magellan Seamounts: Early Cretaceous record of the South Pacific isotopic and thermal anomaly. J. Geophys. Res., 94:10501-10523.

Staudigel, H., Park, K.-H., Pringle, M.S., Rubenstone, J.L., Smith, W.H.F., and Zindler, A., 1991. The longevity of the South Pacific isotopic and thermal anomaly. Earth Planet. Sci. Lett., 102:24-44.

Sun, S.-S., and McDonough, W.F., 1989. Chemical and isotopic systematics of oceanic basalts: implications for mantle composition and processes. In Saunders, A.D., and Norry, M.J. (Eds.), Magmatism in the Ocean Basins. Geol. Soc. Spec. Publ. London, 42:313-345.

Wilkinson, J.F.G., and Hensel, H.D., 1988. The petrology of some picrites from Mauna Loa and Kilauea volcanoes, Hawaii. Contrib. Mineral. Petrol., 98:326-345.

Winterer, E.L., Natland, J.H., van Waasbergen, R.J., Duncan, R.A., McNutt, M.K., Wolfe, C.J., Premoli Silva, I., Sager, W.W., and Sliter, W.V., 1993. Cretaceous guyots in the Northwest Pacific: an overview of their geology and geophysics. In Pringle, M.S., Sager, W.W., Sliter, W.V., and Stein, S. 
(Eds.), The Mesozoic Pacific: Geology, Tectonics, and Volcanism. Geophys. Monogr., Am. Geophys. Union, 77:307-334.

Wright, E., 1986. Petrology and geochemistry of shield-building and posterosional lava series of Samoa: implications for mantle geochemistry and magma genesis [Ph.D. thesis]. Univ. of Calif., San Diego.

Date of initial receipt: 3 February 1994

Date of acceptance: 13 July 1994

Ms 144SR-028

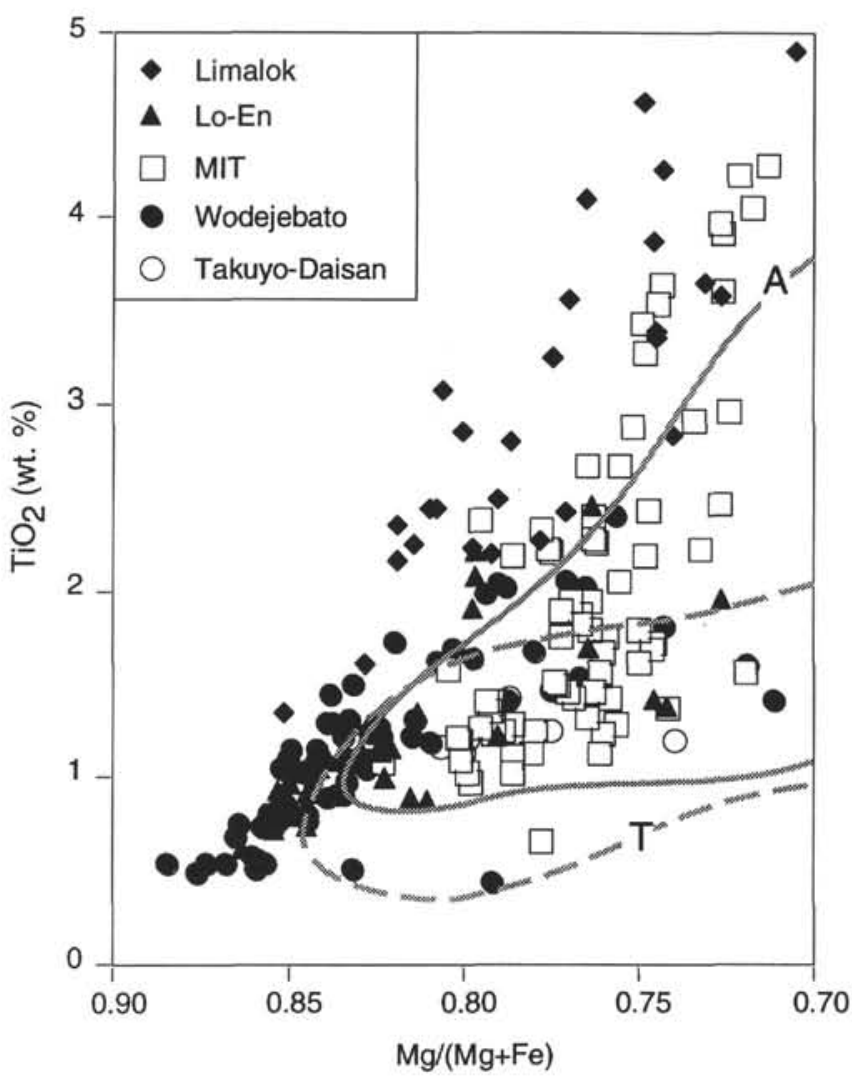

Figure 7. $\mathrm{TiO}_{2}$ vs. $\mathrm{Mg} /(\mathrm{Mg}+\mathrm{Fe})$ for Leg 144 clinopyroxenes. $\mathrm{Mg}$ and $\mathrm{Fe}$ calculated from structural formulas based on six oxygens with all $\mathrm{Fe}$ assumed to be $\mathrm{Fe}^{2+}$. Fields of Hawaiian alkalic (A) and tholeiitic (T) phenocrysts are based on data from Fodor et al. (1975), Clague et al. (1980), Garcia etal. (1986), Chen et al. (1990), and Frey et al. (1990). 


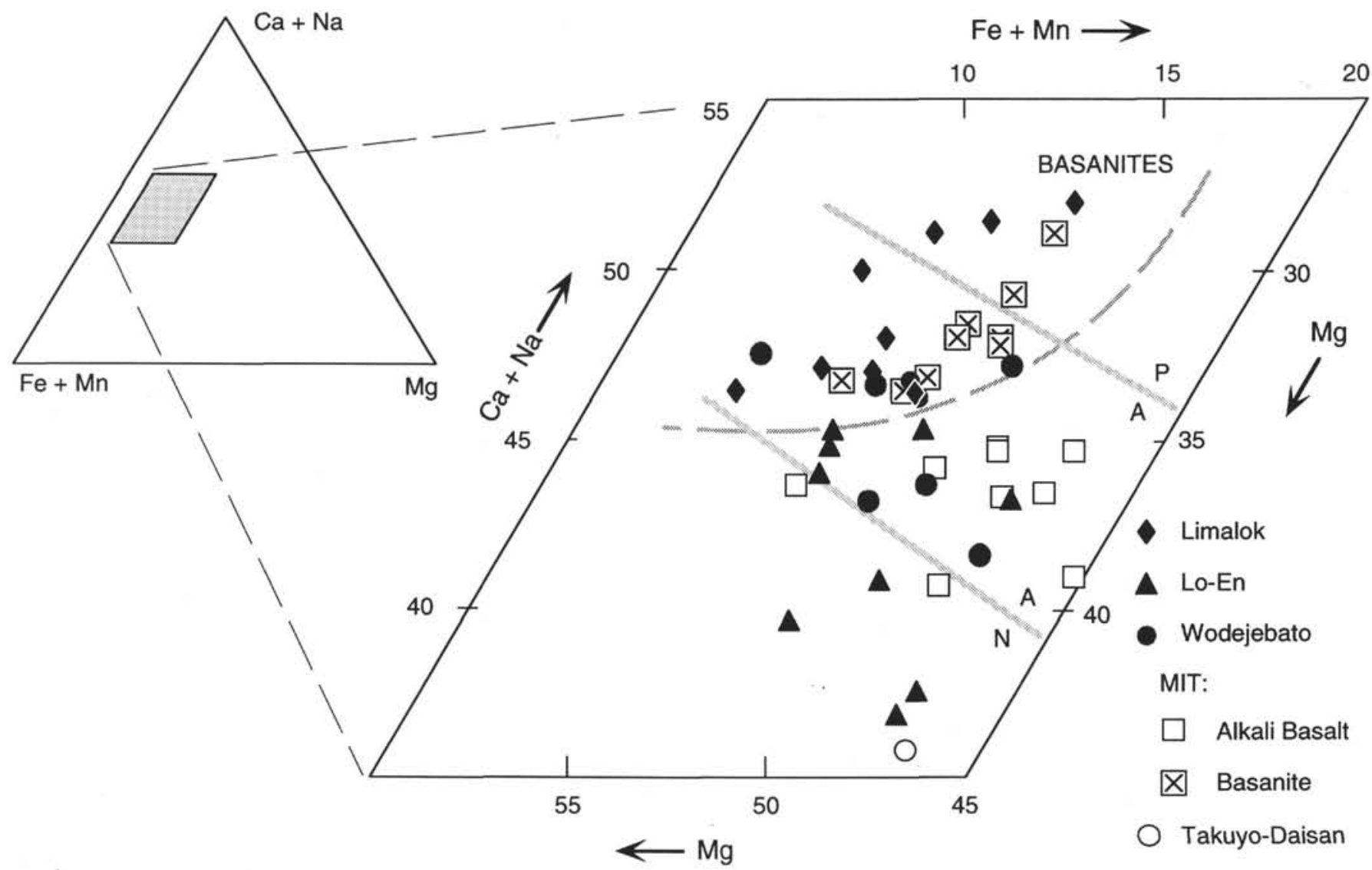

Figure 8. Groundmass clinopyroxene compositions plotted in the $(\mathrm{Fe}+\mathrm{Mn})-\mathrm{Mg}-(\mathrm{Ca}+\mathrm{Na})$ ternary diagram after Le Bas (1962). Values are calculated from structural formulas based on six oxygens. Solid gray lines separate LeBas' fields for nonalkaline (lowermost field; N), alkaline (A), and peralkaline (uppermost field; P) lavas. Dashed gray line marks the lower boundary of the Leg 144 basanite field.

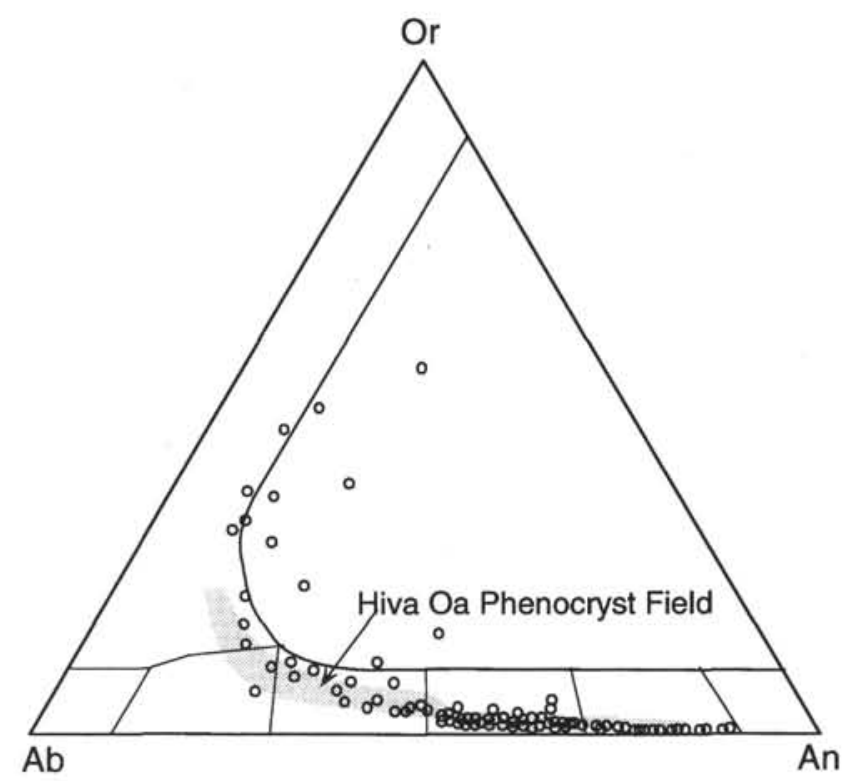

Figure 9. Compositions of all analyzed Leg 144 feldspars in the orthoclasealbite-anorthite feldspar ternary. The shaded field is for phenocrysts from Hiva Oa Island, Marquesas (data of Gonzales-Marabel, 1984). 


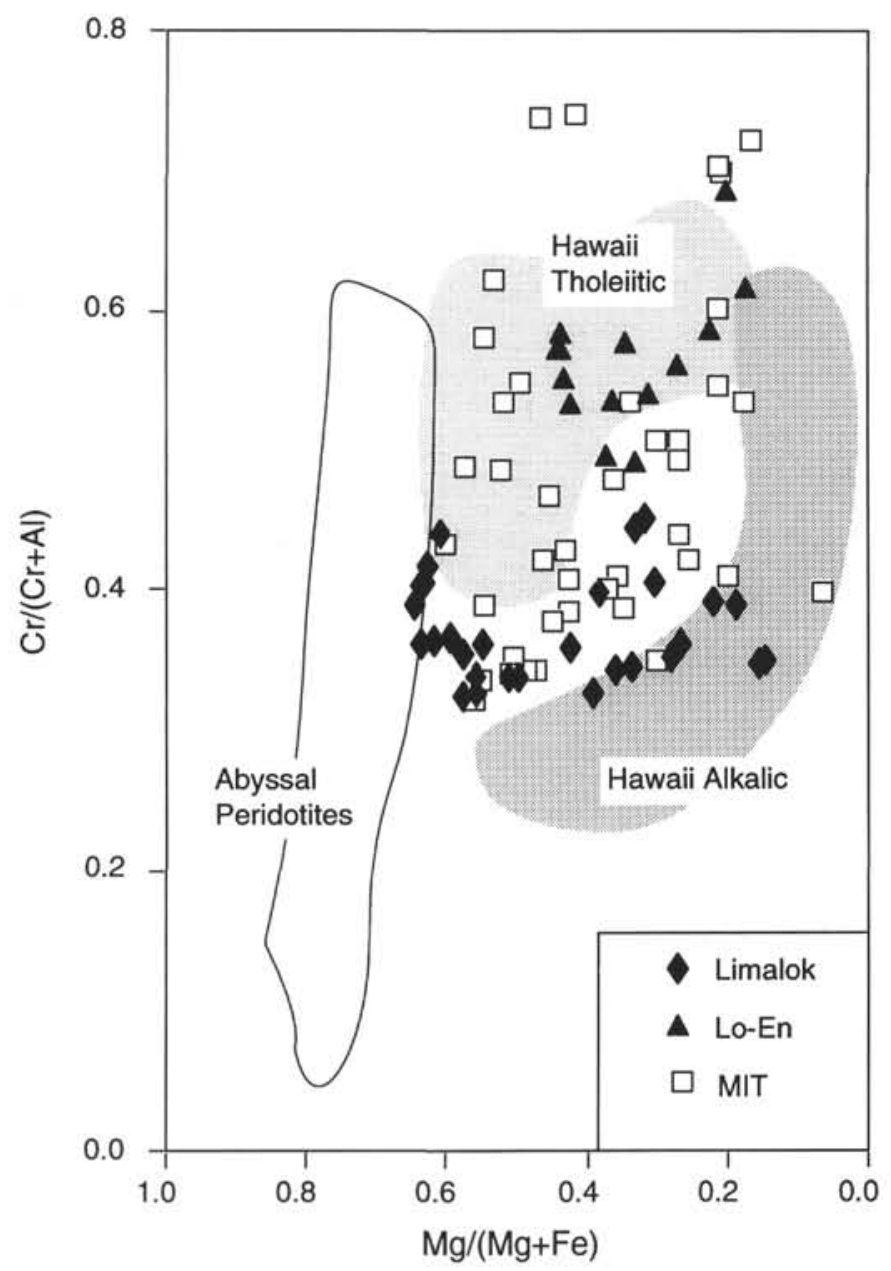

Figure $10 . \mathrm{Cr} /(\mathrm{Cr}+\mathrm{Al}) \mathrm{vs} . \mathrm{Mg} /(\mathrm{Mg}+\mathrm{Fe})$ for Leg 144 spinel phenocrysts in lavas from Sites 871, 874, and 878. Fields for Hawaiian tholeiitic and alkalicseries lavas are based on data from Clague et al. $(1980,1982)$ and Wilkinson and Hensel (1988). Abyssal peridotite field from Dick and Bullen (1984) is shown for reference. 